\title{
Market Assessment of Biomass Gasification and Combustion Technology for Small- and Medium-Scale Applications
}

Technical Report NREL/TP-7A2-46190 July 2009

David Peterson and Scott Haase 


\section{Market Assessment of Biomass Gasification and Combustion Technology for Small- and Medium-Scale Applications}

David Peterson and Scott Haase

Prepared under Task No. IGST.9034

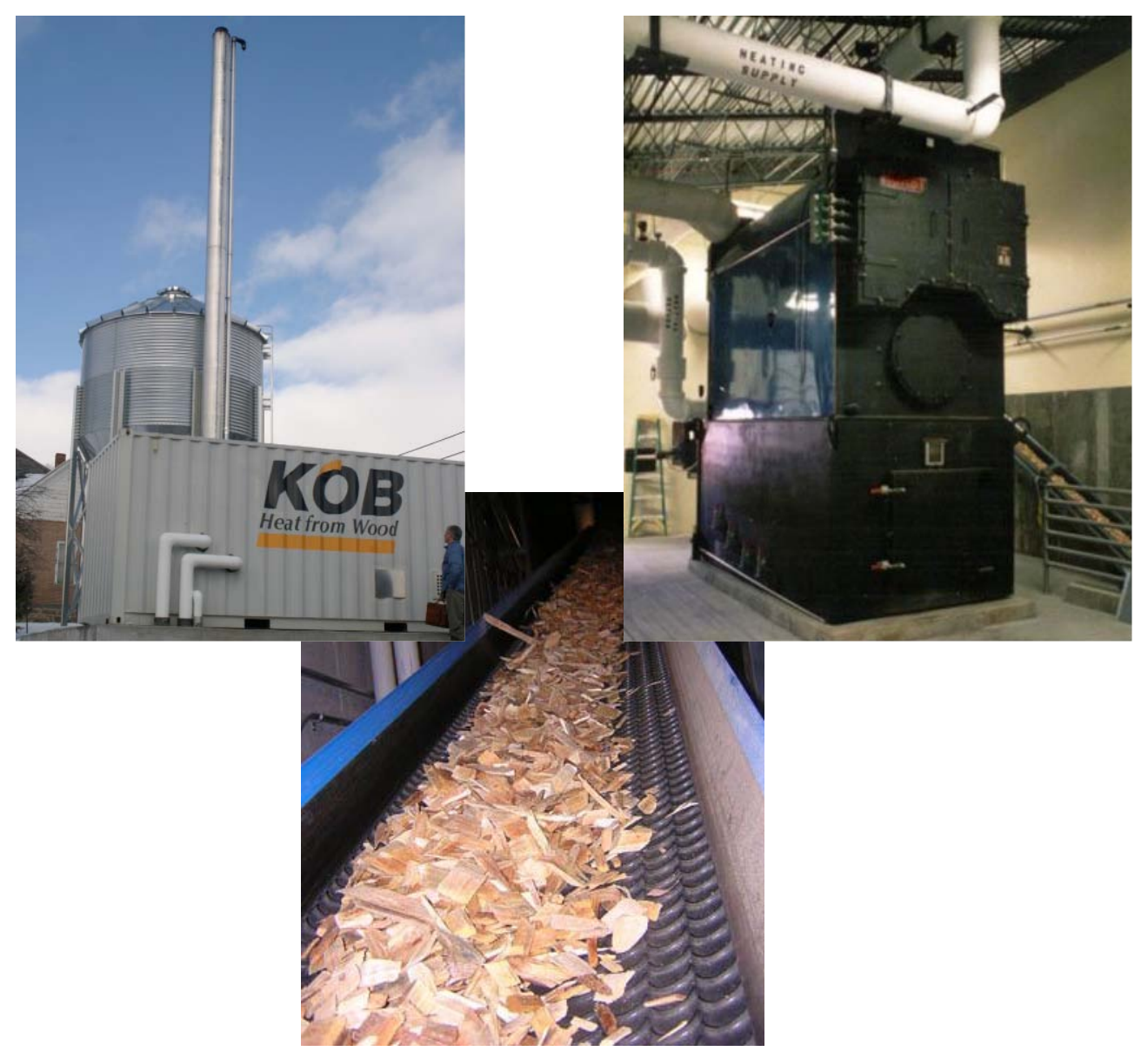

National Renewable Energy Laboratory 1617 Cole Boulevard, Golden, Colorado 80401-3393 303-275-3000 • www.nrel.gov

NREL is a national laboratory of the U.S. Department of Energy

Office of Energy Efficiency and Renewable Energy

Operated by the Alliance for Sustainable Energy, LLC

Contract No. DE-AC36-08-G028308

Technical Report NREL/TP-7A2-46190 July 2009

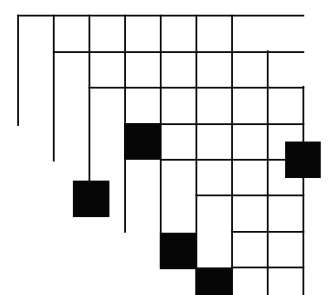




\section{NOTICE}

This report was prepared as an account of work sponsored by an agency of the United States government. Neither the United States government nor any agency thereof, nor any of their employees, makes any warranty, express or implied, or assumes any legal liability or responsibility for the accuracy, completeness, or usefulness of any information, apparatus, product, or process disclosed, or represents that its use would not infringe privately owned rights. Reference herein to any specific commercial product, process, or service by trade name, trademark, manufacturer, or otherwise does not necessarily constitute or imply its endorsement, recommendation, or favoring by the United States government or any agency thereof. The views and opinions of authors expressed herein do not necessarily state or reflect those of the United States government or any agency thereof.

Available electronically at http://www.osti.gov/bridge

Available for a processing fee to U.S. Department of Energy and its contractors, in paper, from:

U.S. Department of Energy

Office of Scientific and Technical Information

P.O. Box 62

Oak Ridge, TN 37831-0062

phone: 865.576 .8401

fax: 865.576 .5728

email: mailto:reports@adonis.osti.gov

Available for sale to the public, in paper, from:

U.S. Department of Commerce

National Technical Information Service

5285 Port Royal Road

Springfield, VA 22161

phone: 800.553.6847

fax: 703.605.6900

email: orders@ntis.fedworld.gov

online ordering: http://www.ntis.gov/ordering.htm 


\section{Acknowledgments}

The authors wish to thank Mark Sinclair, Executive Director of the Clean Energy States

Alliance, and Charles Kubert for their support of this project. In addition, we thank those vendors who provided information on their companies and technologies.

Title page images courtesy of the Biomass Energy Resource Center and A3 Energy Partners.

The project team included Alexander Dane.

\section{Laboratory Point of Contact}

Scott Haase

National Renewable Energy Laboratory

Phone: (303) 275-3057

E-mail: scott.haase@,nrel.gov 


\section{List of Acronyms}

CESA
CHP
EPA
Mbtu
MSW
NREL
ORC
TAP
WWTP

Clean Energy States Alliance combined heat and power U.S. Environmental Protection Agency one million $(1,000,000)$ Btu municipal solid waste National Renewable Energy Laboratory Organic Rankine Cycle Technical Assistance Project wastewater treatment plant 


\section{Executive Summary}

At the request of the Clean Energy States Alliance (CESA), the National Renewable Energy Laboratory prepared this market assessment of gasification and direct combustion technologies that utilize solid biomass to generate heat, power, or combined heat and power (CHP) for smallto medium-scale applications. Solid biomass refers to primarily wood and agricultural resources. The report contains the following:

- An overview of solid biomass resources in the United States.

- Description of gasification and combustion conversion technologies that utilize solid biomass to generate heat, power, and CHP.

- Discussion of the strengths and weaknesses of gasification and combustion technologies.

- Assessment of the commercial status of gasification and combustion technologies.

- Summary of gasification and combustion system economics.

- Market potential for small- to medium-scale gasification and combustion systems.

- An inventory of direct combustion system suppliers.

- An inventory of gasification technology companies.

The major findings and conclusions of the market assessment include the following:

- Direct combustion boiler systems that generate heat, power, or CHP are available commercially from a number of manufacturers.

- Close-coupled gasification boiler systems to generate heat, power, or CHP are commercially available from a number of manufacturers.

- Two-stage gasification systems designed to generate heat, power, or CHP largely are in development, with a number of technologies currently in the demonstration phase.

- A searchable database of operating combustion and gasification systems designed to generate heat, power, or CHP is needed for all projects built in the United States.

- A national assessment of the market potential for direct combustion and gasification systems that generate heat, power, or CHP should be commissioned.

- An online registry of all operating small-scale and community-scale direct combustion and gasification systems that convert biomass into heat, power, or CHP in the United States should be created and maintained. 


\section{Table of Contents}

Acknowledgments ................................................................................................................................. iv

List of Acronyms ..............................................................................................................................

Executive Summary ...............................................................................................................

Table of Contents ................................................................................................................................... vii

List of Figures............................................................................................................................................ viii

List of Tables ......................................................................................................................................... viii

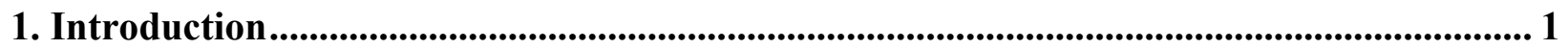

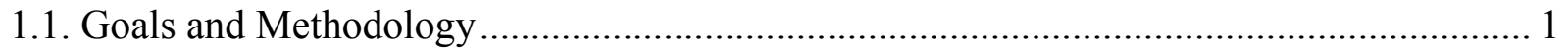

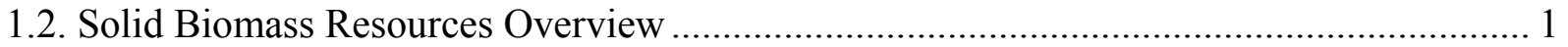

2. Conversion Technologies...................................................................................................................... 6

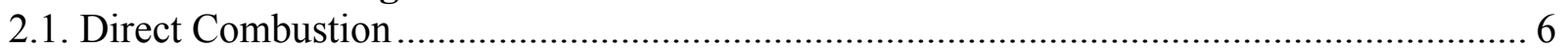

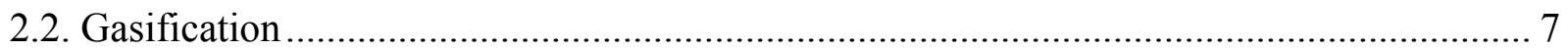

2.3. Direct Combustion and Gasification Strengths and Weaknesses ....................................... 8

3. Commercial Status of Conversion Technologies............................................................................ 9

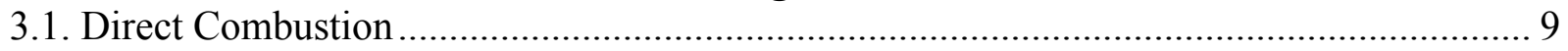

3.1.1. Harney County District Hospital (Oregon) …………..................................................... 9

3.1.2. Darby Public Schools (Montana) ............................................................................. 10

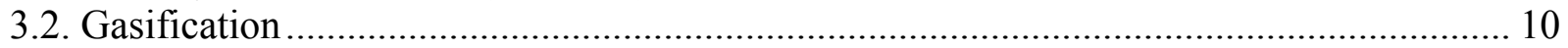

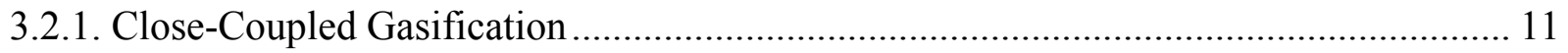

3.2.1.1. Middlebury College Biomass Gasification Plant........................................... 12

3.2.1.2. North Country Hospital................................................................................... 12

3.2.2. Two-Stage Gasification ......................................................................................... 12

4. Project Costs............................................................................................................................... 13

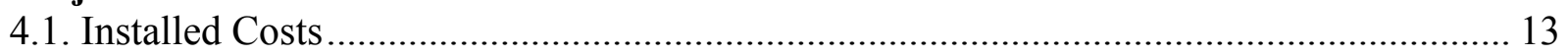

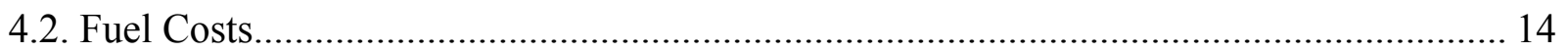

5. Market Potential ..................................................................................................................................... 15

6. Conclusions and Recommendations...................................................................................... 16

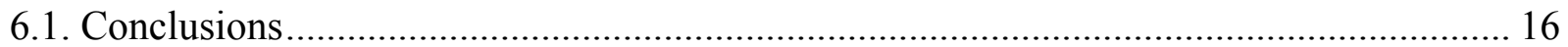

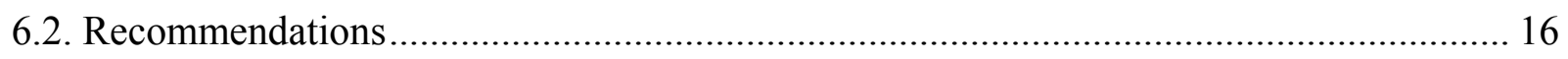

7. References.......................................................................................................................................... 17

Appendix A. Biomass Resource Assessment ............................................................................ 18

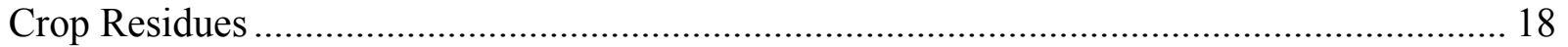

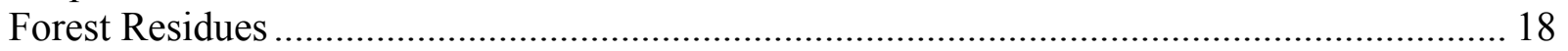

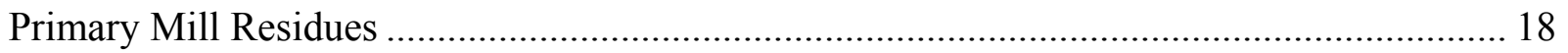

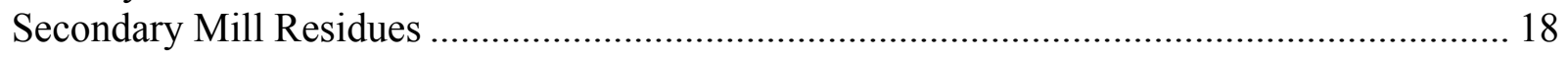

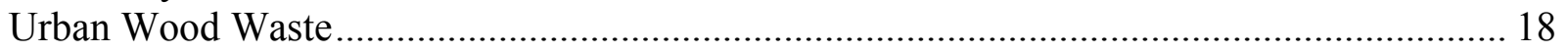

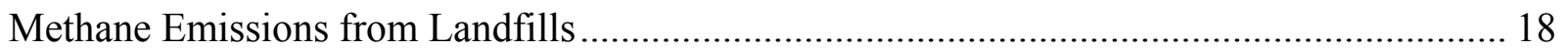

Methane Emissions from Manure Management …………............................................... 18

Methane Emissions from Wastewater Treatment Plants ........................................................ 18

Appendix B. Direct Combustion System Manufacturers............................................................... 19

Appendix C. Direct Combustion, Direct-Fired, and Indirect-Fired Technology Companies

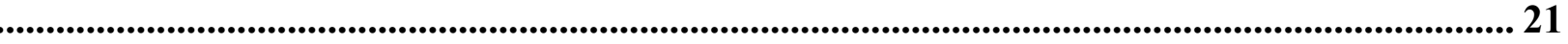

Appendix D. Gasification Technology Companies ............................................................................. 22 


\section{List of Figures}

Figure 1. Total U.S. renewable energy consumption, 2007................................................... 2

Figure 2. Total biomass resources available in the United States by county, 2005 ........................ 4

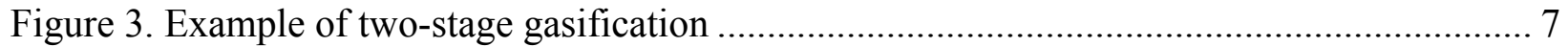

Figure 4. Diagrams of (A) fixed-bed and (B) fluidized-bed gasification systems......................... 8

Figure 5. KÖB wood pellet boiler and pellet silo installed at Harney County District Hospital,

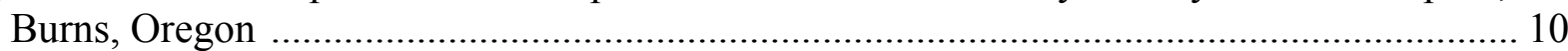

Figure 6. Uniconfort close-coupled gasification system............................................................. 11

Figure 7. Nexterra Energy Corporation facility at University of South Carolina.......................... 12

Figure 8. Community Power Corporation's unit (under the awning) in California....................... 13

Figure 9. Simple payback period for various prices of wood and natural gas ............................. 15

\section{List of Tables}

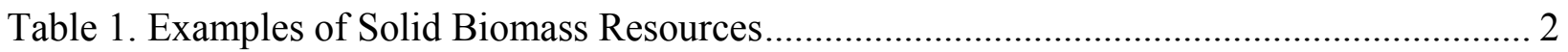

Table 2. Wood Chips and Pellets Comparison .......................................................................... 6

Table 3. Strengths and Weaknesses of Conversion Technologies.................................................. 9

Table 4. Installed Costs for Direct Combustion Systems ………………………....................... 14

Table 5. Comparison of Various Fuels (\$ per Mbtu) ……………………................................... 15 


\section{Introduction}

The Clean Energy States Alliance (CESA) - a nonprofit organization composed of clean energy funds and state agencies from 18 member states-requested technical assistance from the National Renewable Energy Laboratory (NREL) through the U.S. Department of Energy's (DOE) Technical Assistance Project (TAP). CESA requested a market assessment of small- and medium-scale biomass gasification technologies that use solid biomass to generate heat, power, or combined heat and power (CHP). Solid biomass refers to wood and agricultural resources.

\subsection{Goals and Methodology}

The primary purpose of this report is to provide CESA members with a market assessment of small- and medium-scale biomass gasification and combustion technology. For this purpose, this assessment provides:

- An overview of solid biomass resources available in the United States.

- Description of gasification and combustion conversion technologies that utilize solid biomass to generate heat, power, and CHP.

- Discussion of the strengths and weaknesses of gasification and combustion technologies.

- Assessment of the commercial status of gasification and combustion technologies.

- Summary of gasification and combustion system economics.

- Market Potential for small to medium-scale gasification and combustion systems.

- An inventory of direct combustion system suppliers.

- An inventory of gasification technology companies.

The report focuses on biomass gasification and combustion systems with a capacity of less than $5 \mathrm{MW}$ or 50 million Btu/hour (Mbtu/hr), but it does not provide a review of residential-scale systems. Primary applications considered for the report were thermal, CHP, and district heating. To be included in the direct combustion technology company list, systems must be commercially available in the U.S. market. For gasification technology, companies listed in the inventory should have in development technology that is intended for distribution in the U.S. market.

The authors obtained the information contained in this report through phone interviews with experts from both inside and outside of NREL, industry representatives, company Web sites, publicly available reports, and presentations prepared by NREL technical staff. Mention of a company or a process in this report does not constitute a recommendation or endorsement by NREL or DOE. It is the authors' intent to update this report periodically. If a company wishes to be considered for possible inclusion in future issues, please contact the laboratory point of contact listed in the Acknowledgments.

\subsection{Solid Biomass Resources Overview}

Renewable energy resources account for $6.7 \%$ of the total energy consumed in the United States [1]. If liquid biofuels are included, then biomass energy constitutes the greatest source of renewable energy in the United States. Figure 1 shows that biomass energy (consisting of wood energy, biofuels, and waste energy) currently provides more than half of the renewable energy consumed in the United States, with approximately two-thirds of the total biomass energy being used to generate heat, power, or CHP through wood energy. 


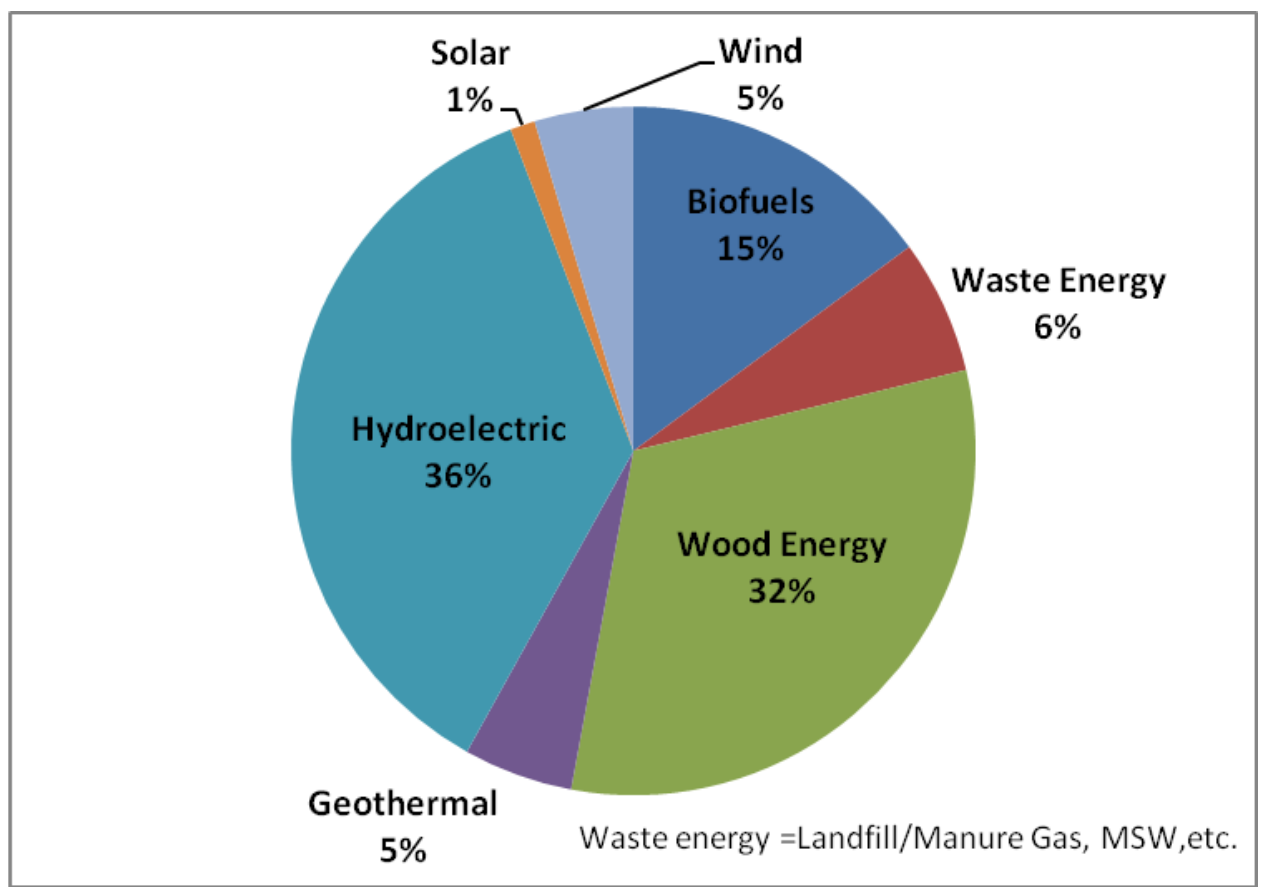

Figure 1. Total U.S. renewable energy consumption, 2007 [1]

The feasibility of a system that utilizes solid biomass to generate heat, power, or CHP largely depends on the availability of feedstocks. Table 1 provides a list of potential solid biomass feedstocks. Although all of these resources are possible feedstocks, wood residues are used by a significant majority of operating biomass facilities that generate heat, power, or CHP in the United States.

Table 1. Examples of Solid Biomass Resources

\begin{tabular}{|c|c|c|}
\hline Wood Residues & Agriculture Residues & Energy Crops \\
\hline Mill residues & Corn stover & Switchgrass \\
(sawdust, etc.) & Wheat straw & Hybrid willow \\
Urban wood waste & Rice hulls & Hybrid poplar \\
Forest thinnings & Sugarcane bagasse & \\
& Animal waste & \\
& & \\
&
\end{tabular}

Locating and quantifying potential sources of available feedstock is vital to the success of a biomass project. Figure 2 provides a graphical representation of the geographic distribution of potential biomass resources in the United States (Appendix A lists and defines the biomass resources included in Figure 2). Agricultural, forest, and mill residues represent approximately $70 \%$ of the total biomass resources shown. 
Starting in fall 2009, county-level biomass resource estimates will be available on line through an interactive mapping and analysis tool. ${ }^{\text {a }}$ Past resource assessment efforts usually were static and did not allow user analysis or manipulation of the data. This new tool enables users to select a location on the map, quantify the biomass resources available within a user-defined radius, and then estimate the total thermal energy or power that could be generated by recovering a portion of that biomass. The tool acts as a preliminary source of biomass feedstock information; however, it cannot take the place of an on-the-ground feedstock assessment.

\footnotetext{
${ }^{a}$ The Biomass Assessment Tool was developed by NREL using funding from the Environmental Protection Agency. The tool is available at http://rpm.nrel.gov/biopower/biopower/launch.
} 


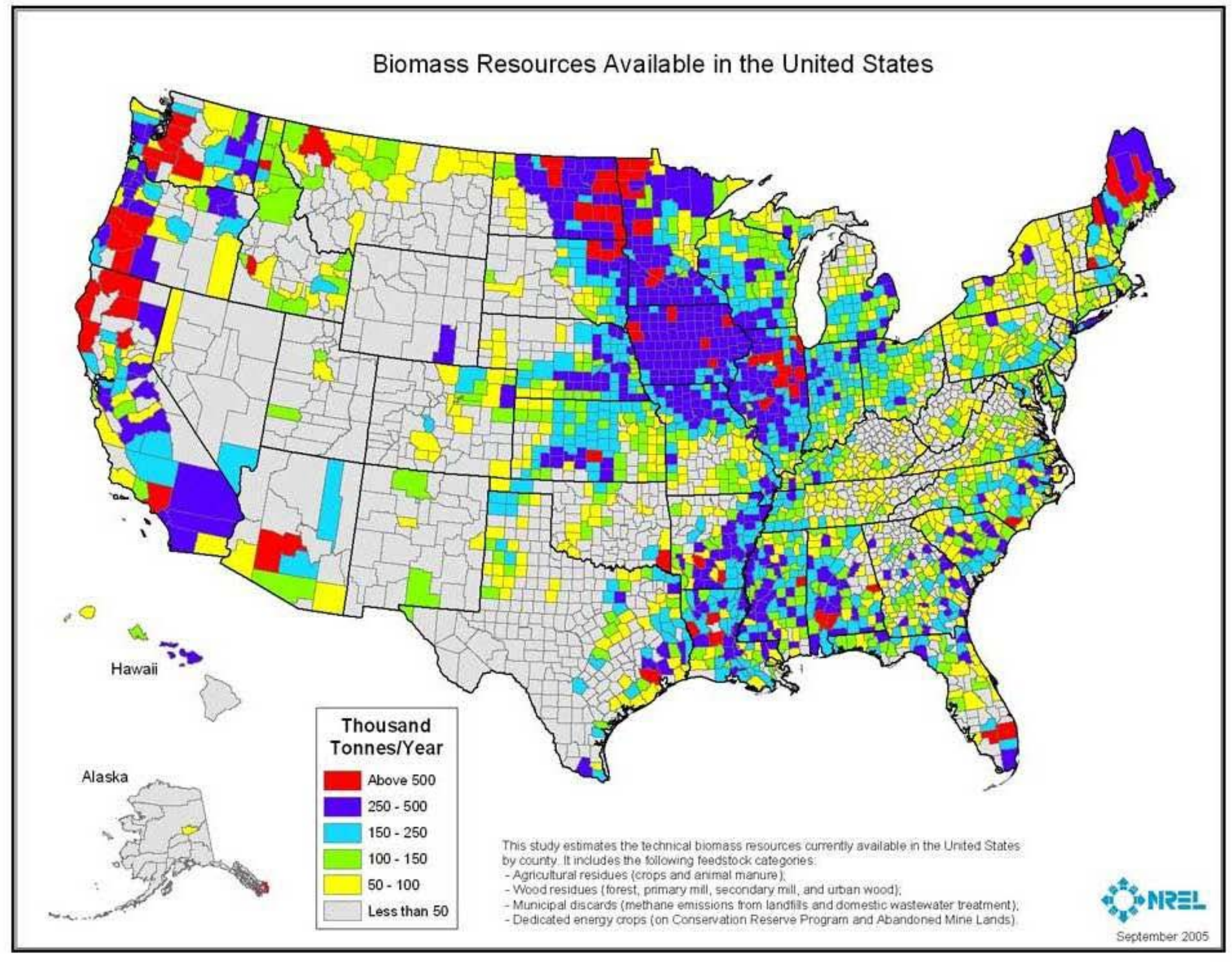

Figure 2. Total biomass resources available in the United States by county, 2005 [2] 
A number of other factors also dictate whether a local feedstock can be used, including:

- Costs associated with the collection, preparation, storage, and transportation of the biomass resource.

- Sustainability of the resource.

- Quality and composition of biomass.

- Ease of converting the biomass resource to energy.

Biomass resource availability is the most important issue in terms of the economics and longterm project sustainability, therefore projects that can utilize a reliable, onsite supply of fuelsuch as sawdust at a wood products plant or wastes from agriculture processing operationshave a distinct advantage. For projects without an onsite fuel supply, securing adequate, longterm feedstock supplies can be expensive and difficult. A number of industry representatives interviewed for this report consider securing a feedstock supply the prime hurdle for larger-scale biomass project development because of the difficulty in finding a supplier willing or able to sign a long-term contract. This is particularly important because a long-term contract for biomass supply often is required to secure project financing.

As noted, woody biomass resources are by far the most commonly utilized solid biomass feedstock. Woody biomass systems typically are designed to handle either wood chips or pellets. Wood chips can be a byproduct of a mill or chipped from scrap wood or whole trees. Although the ideal wood chip is uniform in size and free of dirt, some systems are designed to utilize lesser-quality wood chips. Pellets are a refined wood product and have a lesser moisture content and greater density as compared to wood chips. The characteristics of wood chips and pellets are summarized in Table 2. Additional general information on wood chip and pellet characteristics can be found in the following publications.

- Where Wood Works: Strategies for Heating with Woody Biomass http://www.communitybiomass.com/docs/WhereWoodWorks-Online 1_3.pdf (accessed June 26, 2009).

- Wood Heat Solutions: A Community Guide to Biomass Thermal Projects http://www.uoregon.edu/ cwch/documents/biomass lowres.pdf (accessed June 26, 2009). 
Table 2. Wood Chips and Pellets Comparison

Wood Chips

- Well-suited for larger applications

- A less expensive fuel than pellets

- Irregular quality (moisture content, ash content, size)

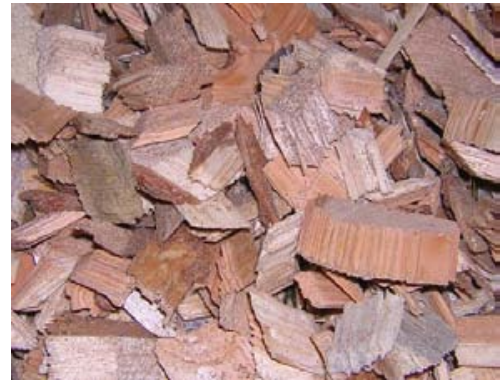

Photos courtesy of Biomass Energy Resources Center

\section{Pellets}

- Typically used in smaller commercial applications (less than 10,000 sq ft)

- A more expensive fuel

- A commodity fuel available from a number of sources

- Pellets systems tend to be less expensive, take up less space, and are more automated than wood-chip systems

- Consistent size, moisture, and heat content

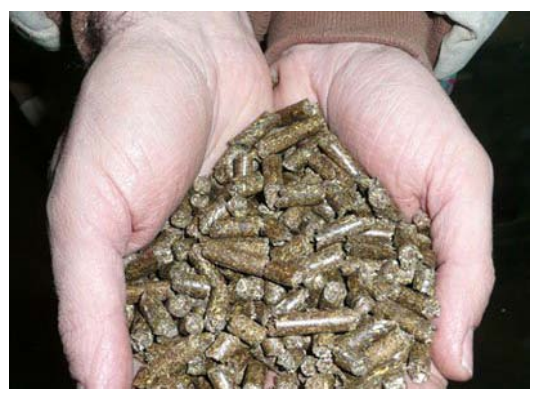

\section{Conversion Technologies}

Technologies that convert solid biomass resources into energy for heat, power, and CHP fall into two general categories, direct combustion and gasification.

\subsection{Direct Combustion}

In the United States and around the world, direct combustion is the most common method of converting biomass resources into heat, power, or CHP. A direct combustion system burns the biomass to generate hot flue gas, which is either used directly to provide heat or fed into a boiler to generate steam. In a boiler system, the steam can be used to provide heat for industrial processes or space heating, and a steam turbine can be used to generate electricity.

The two principle types of direct combustion boiler systems that utilize biomass are fixed-bed (stoker) and fluidized-bed systems. In a fixed-bed system, the biomass is fed onto a grate where it combusts as air passes through the fuel, releasing the hot flue gases into the heat exchanger section of the boiler to generate steam. A fluidized-bed system instead feeds the biomass into a hot bed of suspended, incombustible particles (such as sand), where the biomass combusts to release the hot flue gas. Manufacturers of fluidized-bed systems claim that this technology produces more complete combustion of the feedstock, resulting in reduced $\mathrm{SO}_{2}$ and $\mathrm{NO}_{\mathrm{x}}$ emissions and improved system efficiency. Fluidized-bed boilers also can utilize a wider range of feedstocks. Fluidized-bed systems, however, have greater parasitic loads than stokers. Given proper emissions-control technology, both systems can meet stringent emissions limits. 
Direct combustion biomass facilities that produce electricity through a steam turbine have a conversion efficiency of $15 \%$ to $35 \%$, depending upon the manufacturer; a CHP system can have an overall system efficiency of as much as $85 \%$. The efficiency of a direct combustion biomass system is influenced by a number of factors including: (1) moisture content of the biomass; (2) combustion air distribution and amounts; (3) operating temperatures and pressures; (4) fuel feed handling, distribution, and mixing; and (5) furnace retention time.

Although most direct combustion systems generate power utilizing a steam-driven turbine, a few companies are developing direct combustion technologies that use hot, pressurized air or another medium to drive the turbine. One emerging application is the potential to couple an Organic Rankine Cycle (ORC) power generator to a biomass hot-water source. ORC technology uses hot water to heat a compressed working fluid that has a lower boiling point than water. In this manner, electricity can be produced from low-temperature (approximately $185^{\circ} \mathrm{F}$ and greater), low-pressure sources such as biomass hot-water boilers. ${ }^{\mathrm{b}}$

\subsection{Gasification}

Gasification systems - instead of directly burning the fuel to generate heat-convert biomass into a low-Btu to medium-Btu content combustible gas, which is a mixture of carbon monoxide, hydrogen, water vapor, carbon dioxide, tar vapor, and ash particles. In a close-coupled gasification system, the combustible gas is burned directly for space heat or drying, or burned in a boiler to produce steam. Alternatively, in a two-stage gasification system, tars and particulate matter are removed from the combustible gas, resulting in a cleaner gas suitable for use in a genset, gas turbine, or other application requiring a high-quality gas (Figure 3).

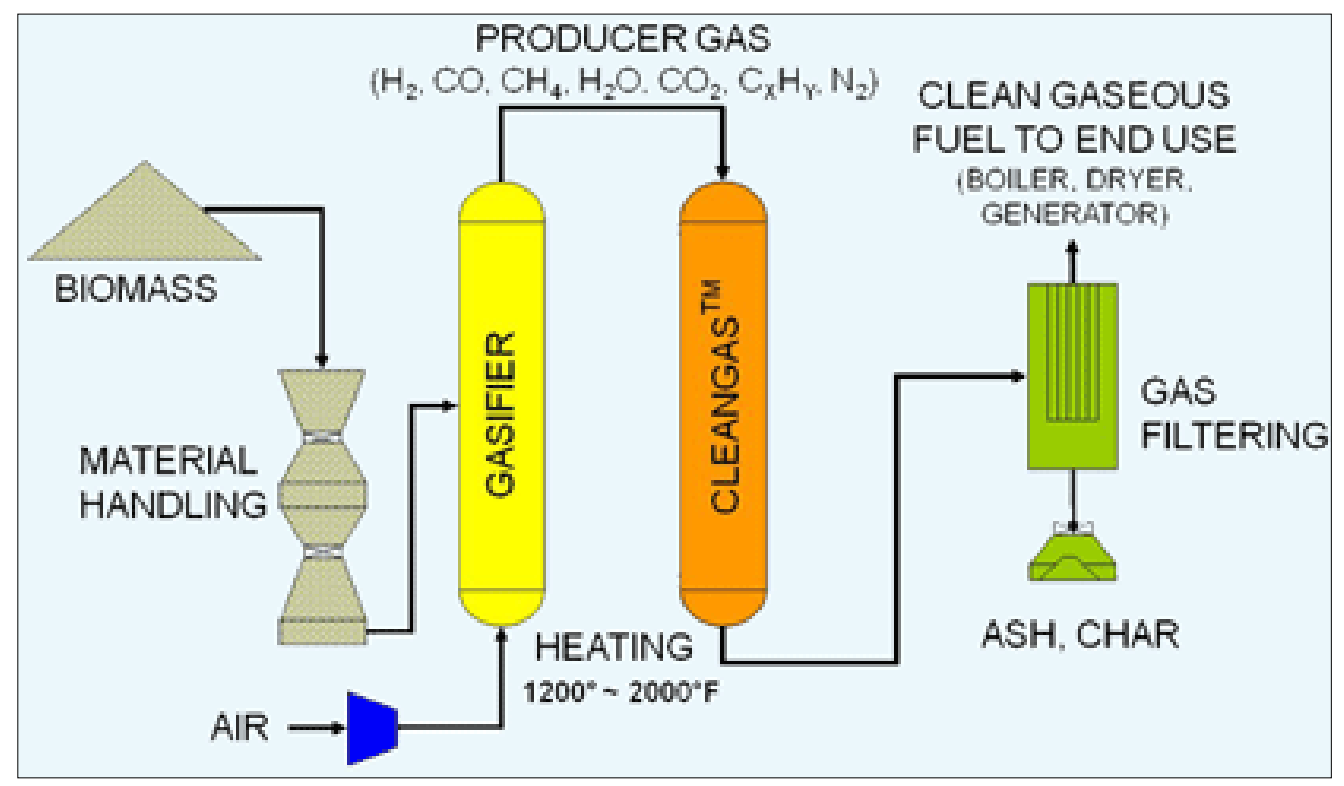

Figure 3. Example of two-stage gasification Courtesy of Frontline Bioenergy

\footnotetext{
${ }^{\mathrm{b}}$ For additional information on ORC, see http://www.gmk.info/ORC_process.603.html?\#.
} 
Fixed bed and fluidized bed are the main categories of gasification conversion technologies, both using similar types of equipment as that used in direct combustion systems (see Figure 4). Fixedbed systems - in which the biomass is piled on top of a grate inside the gasification chamberare a simple, inexpensive, proven technology, but typically they produce a gas with lower heat content. Fluidized-bed gasification systems, in which the combustible gas is generated by feeding the biomass into a hot bed of suspended, inert material, generally offer improved performance, but with greater complexity and cost. The fluidized bed design produces a gas with low tar content but a greater level of particulates as compared to fixed-bed systems. Advantages that fluidized-bed gasification systems have over fixed-bed gasification systems include improved overall conversion efficiency and the ability to handle a wider range of biomass feedstocks.

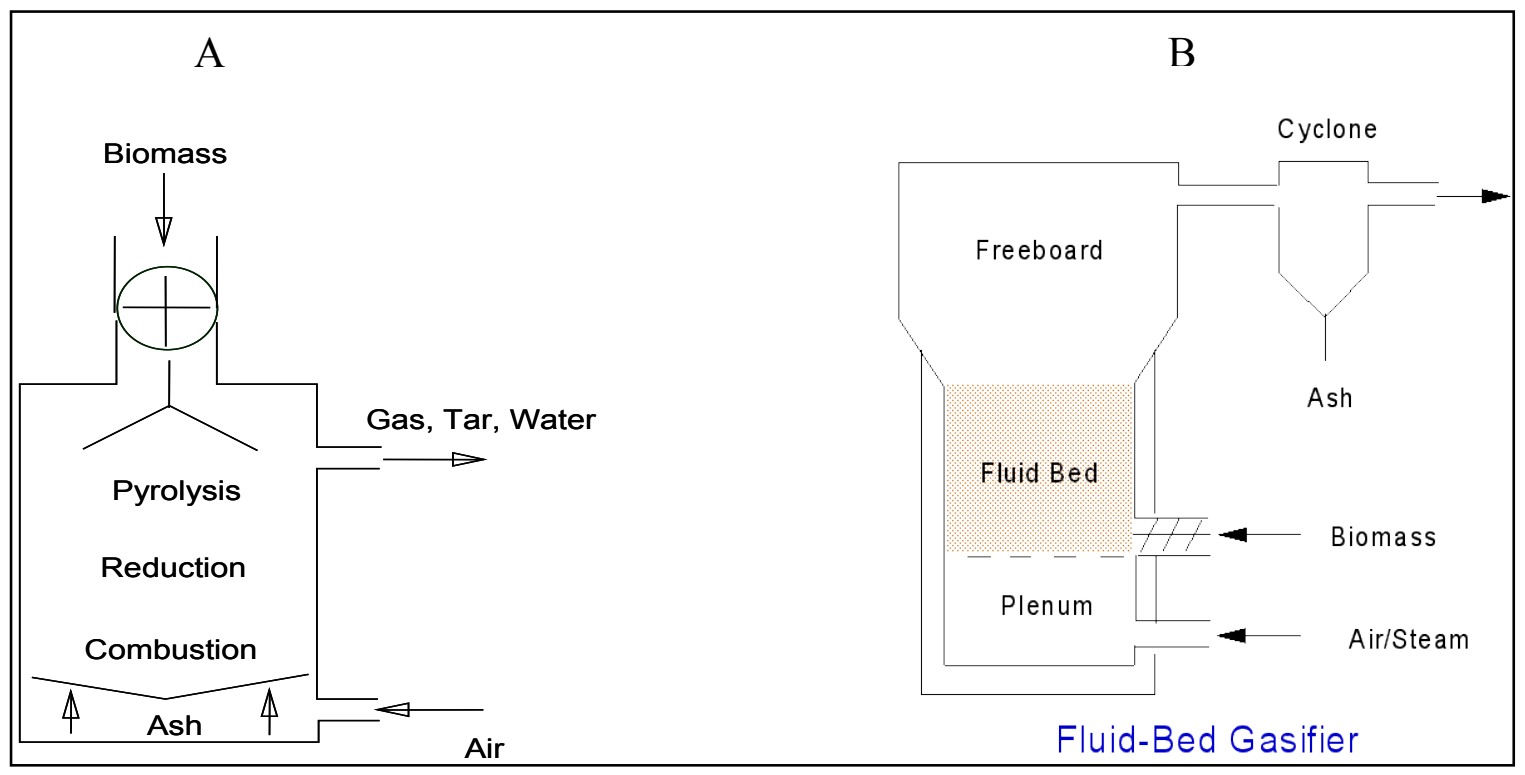

Figure 4. Diagrams of (A) fixed-bed and (B) fluidized-bed gasification systems [3]

Although most biomass resources are suitable for gasification systems, certain high moisture fuels might be uneconomic because of high drying costs. In addition, some agricultural residues generate a combustible gas that requires special processing before it can be utilized in a boiler, turbine, or engine.

\subsection{Direct Combustion and Gasification Strengths and Weaknesses}

Direct combustion and gasification systems each have a number of general strengths and weaknesses (see Table 3). 
Table 3. Strengths and Weaknesses of Conversion Technologies

\begin{tabular}{|c|c|c|}
\hline & Strengths & Weaknesses \\
\hline $\begin{array}{l}\text { Direct } \\
\text { Combustion }\end{array}$ & $\begin{array}{l}\text { - Proven, simple, lower-cost technology } \\
\text { - Equipment is widely available, } \\
\text { complete with warranties } \\
\text { - Fuel flexibility in moisture and size } \\
\text { - Lenders comfortable with technology }\end{array}$ & $\begin{array}{l}\text { - Greater } \mathrm{NO}_{\mathrm{x}}, \mathrm{CO} \text {, and particulate } \\
\text { emissions } \\
\text { - Inefficient conversion process when } \\
\text { generating power alone-some } \\
\text { advanced designs are improving } \\
\text { efficiency } \\
\text { - Requires water if generating power } \\
\text { with a steam turbine }\end{array}$ \\
\hline Gasification & $\begin{array}{l}\text { - Lower } \mathrm{NO}_{x}, \mathrm{CO} \text {, and particulate } \\
\text { emissions } \\
\text { - Potential for more efficient conversion } \\
\text { process when generating power } \\
\text { - Virtual elimination of water needs if } \\
\text { generating power without a steam } \\
\text { turbine (close-coupled systems } \\
\text { excluded) }\end{array}$ & $\begin{array}{l}\text { - Technology is in the development } \\
\text { and demonstration phase (close- } \\
\text { coupled systems excluded) } \\
\text { - Need fuel of uniform size and with } \\
\text { low moisture content }\end{array}$ \\
\hline
\end{tabular}

\section{Commercial Status of Conversion Technologies}

\subsection{Direct Combustion}

Systems that employ direct combustion to convert biomass into energy for heat, power, and CHP are widely utilized and commercially available for small- and medium-scale applications. Direct combustion boiler systems are used for a variety of facility heating purposes and have a solid track record in the field. Additionally, nearly all of the U.S. facilities using biomass to produce power utilize direct combustion technology.

Appendix B provides a non-exclusive list of direct combustion system suppliers that offer commercially available small- to medium-scale direct combustion systems. The systems manufactured by these suppliers range from power-plant scale to small-business scale. Most of the systems are fixed-bed technology designed to utilize wood residues as fuel, and usually are located either onsite at wood manufacturing operations that produce mill residues or in close proximity to accessible feedstock sources. The following two examples examine small- to medium-scale applications of direct combustion technology in the United States.

\subsubsection{Harney County District Hospital (Oregon)}

Harney County District Hospital - a 55,000-square-foot facility_installed a $0.5 \mathrm{Mbtu} / \mathrm{hr}$ wood pellet boiler manufactured by KÖB (Austria) to offset fuel oil, propane, and electricity use [4] (see Figure 5). The boiler supplies domestic hot water and heat to the facility by feeding hot water into a water-source heat pump system. Although the pellet boiler completely eliminated use of heating oil, propane boilers were installed as a backup heat source. In supplying heat to the facility the boiler uses 100 tons of pellets annually, most of which are delivered once every 6 months by a local pellet manufacturer. The pellet boiler's cost totaled $\$ 250,000$ and resulted in annual savings of $\$ 58,000$. The payback period on the system is estimated to be 5 years. 


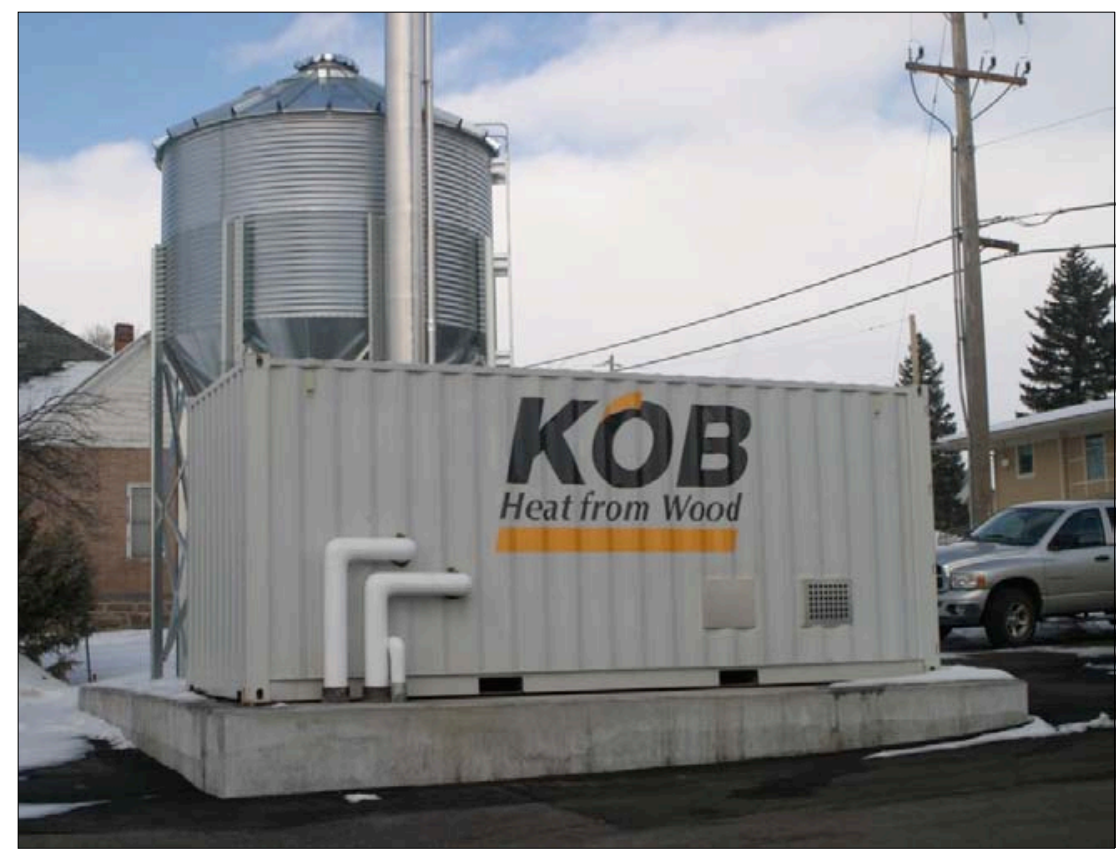

Figure 5. KÖB wood pellet boiler and pellet silo installed at Harney County District Hospital, Burns, Oregon Courtesy of A3 Energy Partners

\subsubsection{Darby Public Schools (Montana)}

With the assistance from the "Fuels for Schools and Beyond" program [5], a biomass boiler system was built in Darby, Montana, to offset heating oil use by supplying heat to three existing schools on a single campus. A $3 \mathrm{Mbtu} / \mathrm{hr}$ Messersmith direct combustion boiler was integrated into a central heat distribution system to provide hot water and low-pressure steam to 82,000 square feet of building space. It burns 750 tons of wood chips annually. Feedstocks are obtained from forest thinning on the nearby public and private lands. During the first year of operation the boiler system offset $79 \%$ of heating oil use. The total project cost for the wood energy system was $\$ 556,000$, and the simple payback period is estimated to be approximately 10 years.

Other direct combustion systems currently are being developed. One such technology is a nonboiler, direct combustion CHP system which, instead of using a steam turbine to generate power, uses another medium - such as pressurized air - to drive the turbine. Appendix C provides a short list of companies involved in the development of non-boiler direct combustion CHP systems in the United States.

\subsection{Gasification}

The market readiness of solid-biomass gasification technology greatly depends on how the system utilizes the combustible gas produced. Close-coupled biomass gasification-boiler systems - in which the gas is fed into and directly burned in a boiler to produce steam for heat and power - to a great extent are a viable, commercially available technology. Two-stage gasification systems - in which the combustible gas is conditioned (cleaned) and then utilized in an engine, a turbine, or as a natural gas substitute - currently are in the developmental and demonstration stage. 


\subsubsection{Close-Coupled Gasification}

Appendix D provides a non-exclusive list of companies currently developing gasification projects in the United States. Note that most companies produce close-coupled biomass gasification-boiler systems. ChipTec Wood Energy is the most established manufacturer of commercially available small- to medium-scale close-coupled systems. Additionally, Uniconfort, an established Italian manufacturer, now is marketing small- to medium-scale systems (Figure 6) in the United States through Alternative Energy Solutions, a subsidiary of Wichita Boiler.

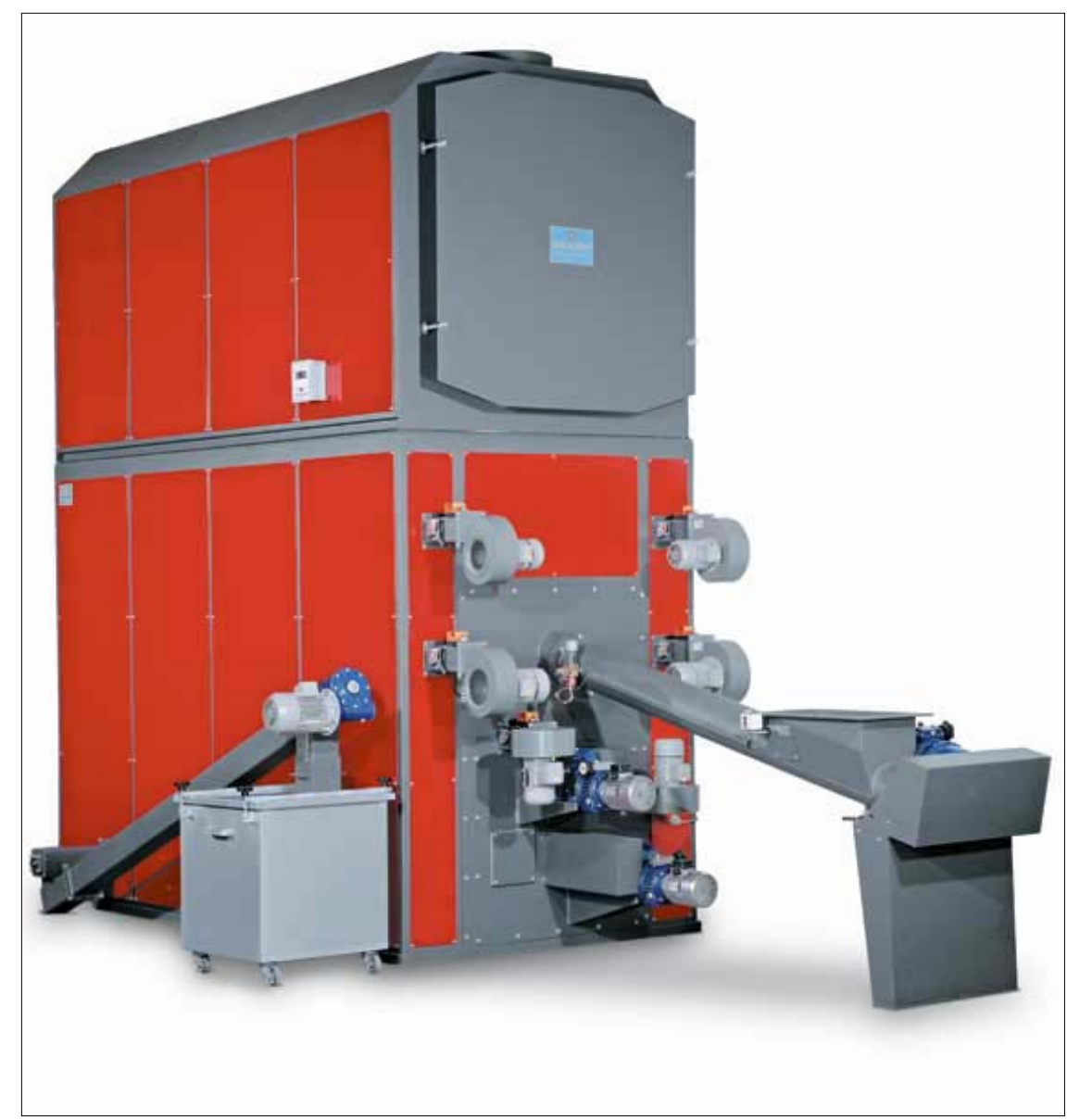

Figure 6. Uniconfort close-coupled gasification system Courtesy of Alternative Energy Solutions

A number of companies specialize in medium to large-scale systems, close-coupled gasificationboiler systems. Nexterra partnered with Johnson Controls to install a large-scale CHP system at the University of South Carolina (see Figure 7), as well as a future system to provide heat at DOE's Oak Ridge National Laboratory. Both facilities will use locally harvested wood feedstocks. A couple of companies - Primenergy and PRM Energy - predominantly have installed industrial-scale heating systems fueled by onsite biomass, mostly agricultural residues at processing sites. 


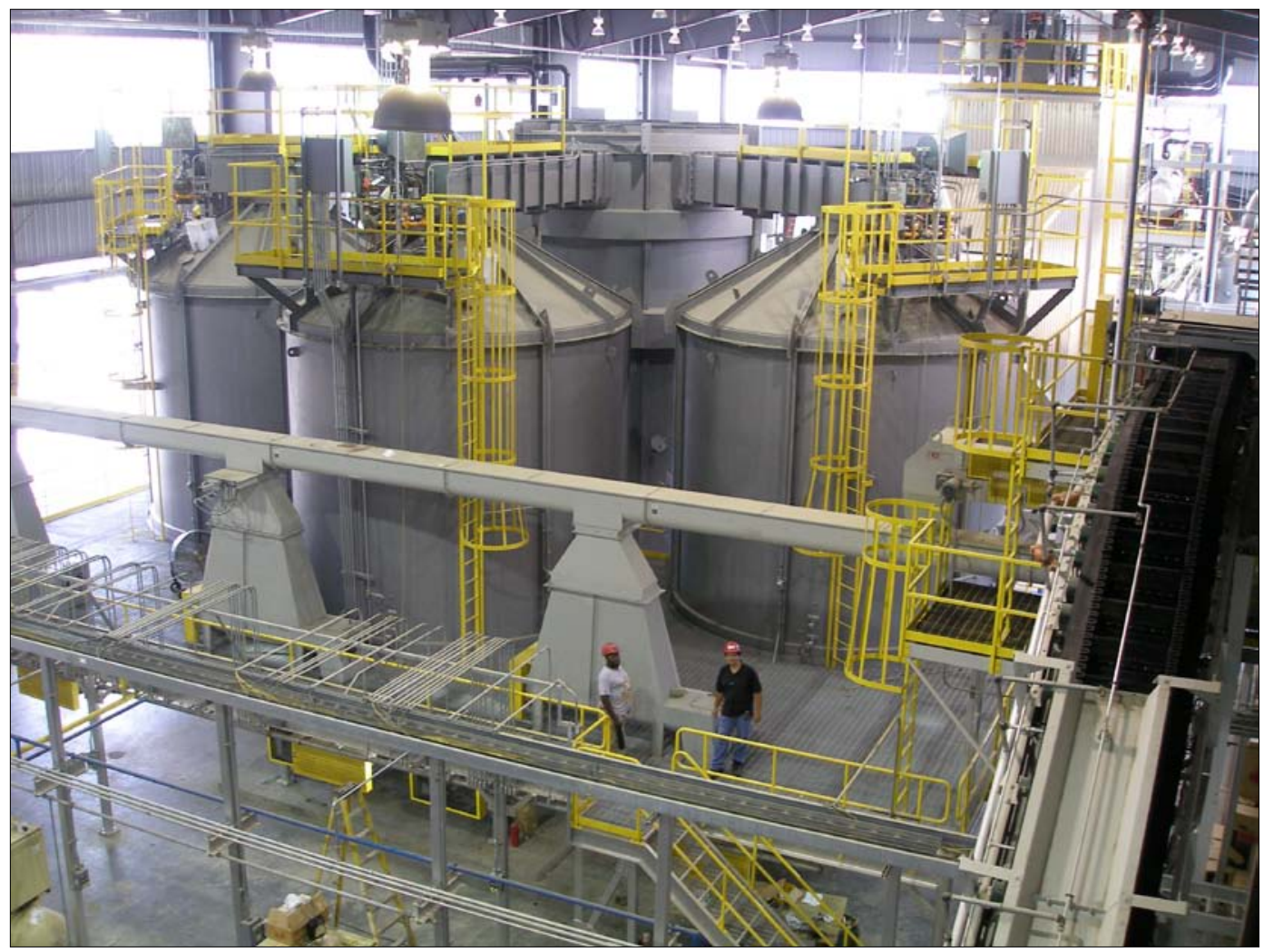

Figure 7. Nexterra Energy Corporation facility at University of South Carolina Courtesy of Nexterra Energy Corp.

The following are examples of close-coupled gasification system applications in Vermont.

\subsubsection{Middlebury College Biomass Gasification Plant [6]}

In February 2009, Middlebury College began operation of a $29 \mathrm{Mbtu} / \mathrm{hr}$ ChipTec close-coupled gasification boiler system. Consuming roughly 20,000 tons of local wood chips per year, the system will generate steam for the college's district energy system, which provides heating, cooling, and domestic hot water to the campus. The system is expected to offset more than 1 million gallons of fuel oil consumed annually by the existing boiler plant. The payback period for the \$12-million system is estimated to be approximately 11 years.

\subsubsection{North Country Hospital}

In response to rising energy costs, North County Hospital in Newport, Vermont, installed a combined heat, cooling, and power biomass close-coupled gasification system in 2005 [12]. The system utilized a ChipTec gasifier and Hurst boiler to produce steam, generating electricity through a steam turbine, usable heat, and cooling through an absorption chiller. The system cost for the 121,000-square-foot facility totaled approximately $\$ 2$ million, and the annual estimated cost savings of the system is $\$ 250,000$.

\subsubsection{Two-Stage Gasification}

A number of companies currently are developing two-staged gasification technology, in which the combustible gas is not burned directly, but instead is conditioned and either fed into an engine/turbine to generate power or used as natural gas substitute for industrial heating. Most—if not all-two-stage technology is in the demonstration phase of the development process and is 
not commercially available. Current technology barriers revolve around efficiently removing impurities from the combustible gas, as well as the low heating value of the conditioned gas.

A small-scale two-stage gasification system example, Community Power Corporation (CPC) has demonstrated a series of $5-\mathrm{kW}$ to $100-\mathrm{kW}$ modular biomass CHP systems at a number of locations across the United States. Intended for use at remote locations in need of distributed heat and power, CPC's gasification technology converts biomass fuels into a clean, combustible gas, which is fed into an engine to generate power. CPC currently has a system operating in California that utilizes walnut shells as a feedstock (shown in Figure 8). A medium- to largescale example of two-stage gasification technology, Frontline Bioenergy has installed a system at a Minnesota ethanol plant that utilizes corn stover as a feedstock. The conditioned gas produced serves as a direct substitute for natural gas used in the corn ethanol plant's processes.

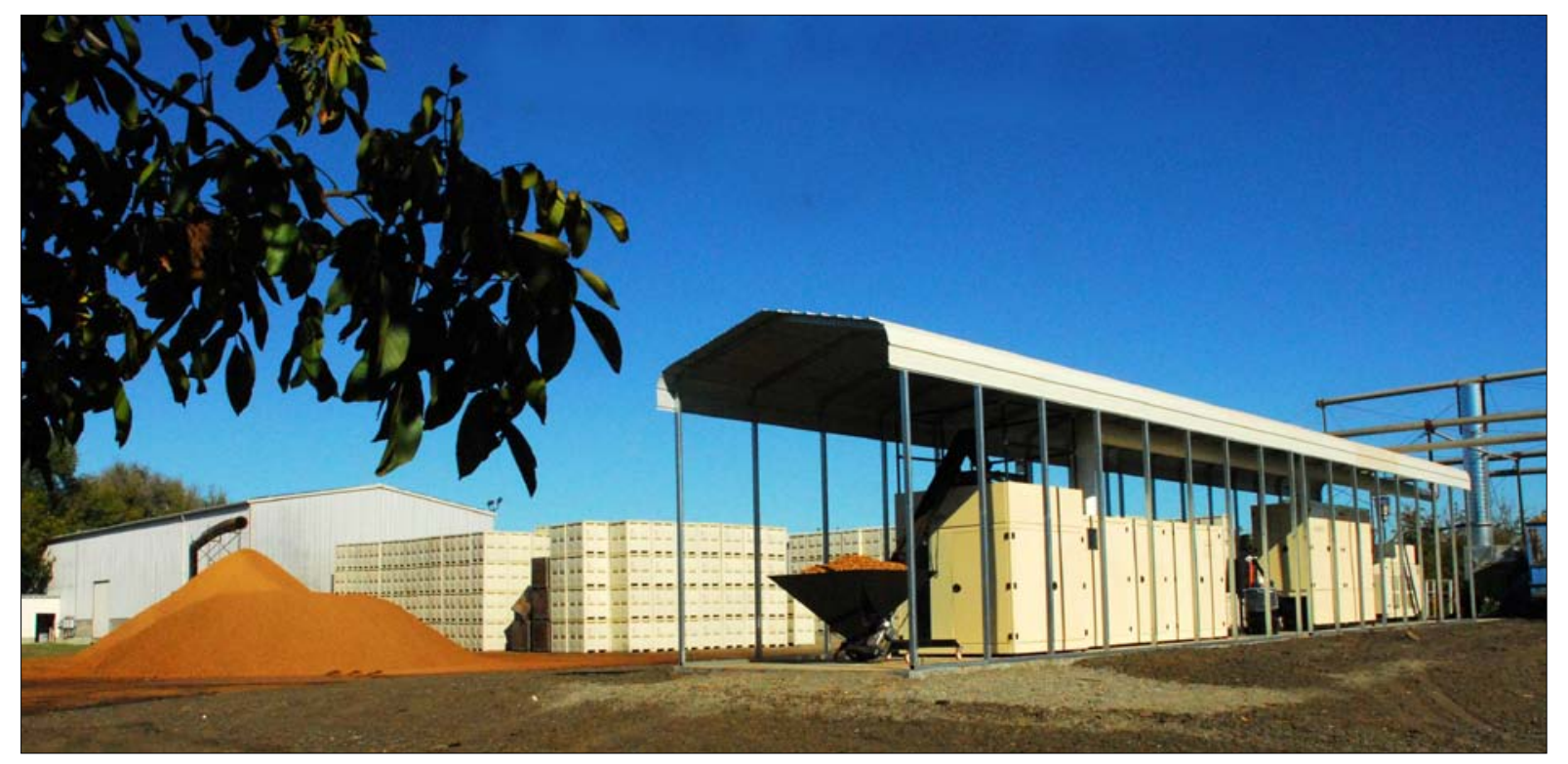

Figure 8. Community Power Corporation's unit (under the awning) in California Courtesy of Community Power Corporation

\section{Project Costs}

\subsection{Installed Costs}

Installed costs for systems that generate heat, power, or both from solid biomass resources are variable and very project specific. Table 4 lists project costs for a number of systems installed within the last 5 years. 
Table 4. Installed Costs for Direct Combustion Systems [7]

\begin{tabular}{|c|c|c|c|c|c|}
\hline Facility Name & Location & $\begin{array}{l}\text { Boiler Size } \\
\text { (Mbtu/hr } \\
\text { output) }\end{array}$ & Project Type & $\begin{array}{l}\text { Wood } \\
\text { Fuel } \\
\text { Type }\end{array}$ & $\begin{array}{l}\text { Total } \\
\text { Project } \\
\text { Cost }\end{array}$ \\
\hline $\begin{array}{l}\text { Bismarck Public } \\
\text { Works Facility }\end{array}$ & Bismarck, ND & 1.0 & Direct combustion, stand alone & Chips & $\$ 220,000$ \\
\hline $\begin{array}{l}\text { Harney District } \\
\text { Hospital }\end{array}$ & Burns, OR & 0.8 & $\begin{array}{l}\text { Direct combustion system tied to } \\
\text { heat-pump system }\end{array}$ & Pellets & $\$ 269,000$ \\
\hline $\begin{array}{l}\text { Troy School } \\
\text { District }\end{array}$ & Troy, MT & 0.7 & $\begin{array}{l}\text { Direct combustion system installed } \\
\text { in existing steam-boiler room }\end{array}$ & Pellets & $\$ 298,755$ \\
\hline $\begin{array}{l}\text { Townsend School } \\
\text { District }\end{array}$ & Townsend, MT & 2.2 & $\begin{array}{l}\text { Direct combustion system using } \\
\text { existing hot-water boilers }\end{array}$ & Pellets & $\$ 425,000$ \\
\hline $\begin{array}{l}\text { Thompson Falls } \\
\text { School District }\end{array}$ & $\begin{array}{l}\text { Thompson } \\
\text { Falls, MT }\end{array}$ & 1.6 & $\begin{array}{l}\text { Close-coupled gasification system } \\
\text { installed in stand-alone building } \\
\text { and tied to existing steam system }\end{array}$ & Chips & $\$ 455,000$ \\
\hline $\begin{array}{l}\text { Victor School } \\
\text { District }\end{array}$ & Victor, MT & 2.6 & $\begin{array}{l}\text { Direct combustion system installed } \\
\text { in and tied to an existing steam } \\
\text { system }\end{array}$ & Chips & $\$ 684,000$ \\
\hline $\begin{array}{l}\text { Philipsburg School } \\
\text { District }\end{array}$ & Philipsburg, MT & 3.9 & $\begin{array}{l}\text { Direct combustion boiler tied to an } \\
\text { existing system }\end{array}$ & Chips & $\$ 970,000$ \\
\hline City of Craig & Craig, AK & 4.0 & $\begin{array}{l}\text { Close-coupled gasification system } \\
\text { installed in stand-alone building } \\
\text { and tied to existing steam system }\end{array}$ & Chips & $\$ 1,400,000$ \\
\hline $\begin{array}{l}\text { University of } \\
\text { Montana, Western }\end{array}$ & Dillon, MT & 14.0 & $\begin{array}{l}\text { Close-coupled gasification system } \\
\text { added to an existing steam system }\end{array}$ & Chips & $\$ 1,400,000$ \\
\hline $\begin{array}{l}\text { University of South } \\
\text { Carolina }\end{array}$ & Charleston, SC & 72.0 & $\begin{array}{l}\text { Close-coupled gasification CHP } \\
\text { central district steam system }\end{array}$ & Chips & $\$ 16,000,000$ \\
\hline
\end{tabular}

The variable total project cost likely is a reflection of the other costs associated with developing a project outside of the direct combustion or gasification unit cost. These additional costs can include the following elements [7].

- Feasibility study

- Detailed engineering investigation

- Design fees and expenses

- Buildings permit costs

- Air-quality permit costs (including engineering fees)

- Chip storage/boiler building costs

- Mechanical and electrical costs incurred for boiler-building interior
- Feedstock handling-system costs

- Stack costs

- Buried-pipe costs

- Mechanical and electrical integration costs associated with existing boilers

- Remoteness factor (where applicable)

- Construction contingencies

- Escalation factors

\subsection{Fuel Costs}

Project economics are affected dramatically by both the cost of solid biomass feedstock as well as the price of the lowest-price fossil fuel alternative (often natural gas, propane, or heating oil). Figure 9 illustrates how the simple payback period of a $3 \mathrm{Mbtu} / \mathrm{hr}$ system with a total installed capital cost of $\$ 850,000$ is influenced by variations of the price of wood and natural gas. If wood is $\$ 15 /$ ton and natural gas is $\$ 7 / \mathrm{Mbtu}$, for example, then the simple payback term is 11 years. If wood is $\$ 15 /$ ton and natural gas is $\$ 3 / \mathrm{Mbtu}$, then the simple payback is approximately 48 years. 


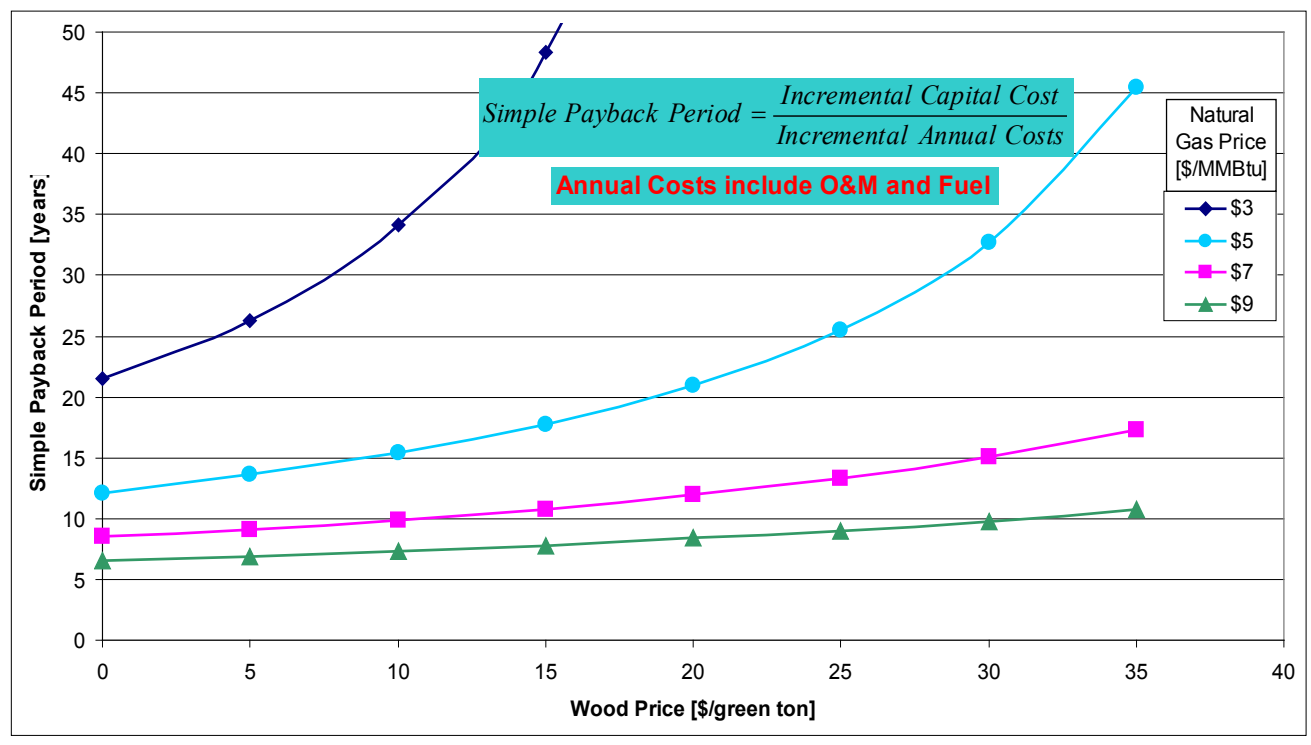

Figure 9. Simple payback period for various prices of wood and natural gas [8]

Table 5 shows a comparison of the cost of various fuels per million Btu of energy produced. The value listed under "efficiency" is the estimated efficiency of the appliance that is converting the fuel to end-use energy.

Table 5. Comparison of Various Fuels (\$ per Mbtu) ${ }^{c}$

\begin{tabular}{|c|c|c|c|c|c|}
\hline Source & Units & $\begin{array}{l}\text { Cost to User } \\
\text { per unit (\$ U.S.) }\end{array}$ & Efficiency & Btu/unit & \$ per Mbtu \\
\hline Chipped biomass & $\$ /$ green ton & $\$ 50.00$ & $75 \%$ & $13,500,000$ & $\$ 4.94$ \\
\hline Wheat straw bales & \$/ton & $\$ 55.00$ & $70 \%$ & $14,000,000$ & $\$ 5.61$ \\
\hline Natural gas & \$/therm & $\$ 0.50$ & $85 \%$ & 100,000 & $\$ 5.88$ \\
\hline Wood/ag pellets & \$/ton & $\$ 130.00$ & $80 \%$ & $15,000,000$ & $\$ 10.83$ \\
\hline Natural gas & $\$ /$ therm & $\$ 1.00$ & $85 \%$ & 100,000 & $\$ 11.76$ \\
\hline Wood/ag pellets & $\$ /$ ton & $\$ 160.00$ & $80 \%$ & $15,000,000$ & $\$ 13.33$ \\
\hline Hardwood pellets & $\$ /$ ton & $\$ 185.00$ & $80 \%$ & $16,600,000$ & $\$ 13.93$ \\
\hline Natural gas & \$/therm & $\$ 1.50$ & $85 \%$ & 100,000 & $\$ 17.65$ \\
\hline Fuel oil & $\$ /$ gallon & $\$ 2.25$ & $85 \%$ & 135,000 & $\$ 19.61$ \\
\hline Natural gas & $\$ /$ therm & $\$ 1.75$ & $85 \%$ & 100,000 & $\$ 20.59$ \\
\hline Propane & \$/gallon & $\$ 2.25$ & $85 \%$ & 91,600 & $\$ 28.90$ \\
\hline Electricity & $\$ / k W h$ & $\$ 0.10$ & $100 \%$ & 3,413 & $\$ 29.30$ \\
\hline
\end{tabular}

\section{Market Potential}

There are no completed studies that estimate the overall market potential for small- and community-scale direct combustion and gasification systems that convert biomass into heat,

${ }^{\mathrm{c}}$ Data provided by Scott Haase, National Renewable Energy Laboratory (2009). 
power, or CHP. The potential to utilize the technology, however, is significant in many parts of the United States. A majority of the market will be the retrofitting of existing fossil-fuel heating systems with biomass boilers; however, the integration of biomass systems into new construction projects should be considered whenever possible.

The market potential for small- and community-scale direct combustion and gasification systems that convert biomass into heat, power, or CHP has not been properly addressed at the national level. Several states, however, have done assessments of the market potential for these systems. Michigan, for example, commissioned a 2007 report to examine the market potential for woody biomass retrofit opportunities in boiler operations within the state [7]. The analysis of an existing boiler database identified 2,300 existing boilers for which retrofits with a wood-fired heating system could result in a projected simple payback period of less than 20 years. A similar study was conducted in Montana in 2006 [9].

\section{Conclusions and Recommendations}

\subsection{Conclusions}

The market for small- and community-scale direct combustion and gasification systems that convert biomass into heat, power, or CHP is developing slowly but steadily. There are countless communities, facilities, and utilities that are either developing or evaluating prospective biomass applications. The market readiness of conversion technologies varies widely however. Systems that employ direct combustion or close-coupled gasification to convert biomass into heat, power, or CHP are commercially available from multiple manufacturers. Systems that utilize two-stage gasification are near-commercial technologies and most manufacturers are actively testing demonstration and pilot units.

\subsection{Recommendations}

The following are some suggestions for follow-up actions for interested states, communities, or facilities:

- Entities wishing to support the development of gasification applications and technologies should consider funding demonstration projects of near-commercial technologies in their states.

- Interested vendors that wish to be included in an updated version of this report should contact Scott Haase at National Renewable Energy Laboratory, phone: 303-275-3057; e-mail: scott.haase@nrel.gov.

- A national assessment of the market potential for small- and community-scale direct combustion and gasification systems that convert biomass into heat, power, or CHP should be commissioned.

- A central clearinghouse or registry of small- to medium-scale systems should be created and maintained. The registry should be searchable online and include a GIS mapping function. 


\section{References}

1. Energy Information Administration (May 2008). U.S. Energy Consumption by Energy Source. http://www.eia.doe.gov/cneaf/alternate/page/renew_energy_consump/table1.html. Accessed June 26, 2009.

2. Milbrandt, A. (2005). A Geographic Perspective on the Current Biomass Resource Availability in the United States. NREL/TP-560-39181. Golden, CO: National Renewable Energy Laboratory.

3. Bain, R. (2006). "Biomass Gasification Presentation." Presented at the USDA Thermochemical Conversion Workshop. NREL Biorefinery Analysis and Exploratory Research Group.

4. http://www.sustainablenorthwest.org/community-biomassworkshop/JB_Harney\%20Co\%20Hospital.pdf (accessed July 17, 2009).

5. http://www.fpl.fs.fed.us/documnts/fplgtr/fpl_gtr173.pdf (accessed July 17, 2009).

6. “Middlebury College Biomass Plant” (December 2008). BioCycle. Vol. 49, No. 12; p. 46.

7. CTA Architects and Engineers et al. 2007. "Exploring Woody Biomass Retrofit Opportunities in Michigan Boiler Operations submitted to Southeast Michigan RC\&D Council, 2007." http://michiganwoodenergy.org/ctareport.php. Accessed June 23, 2009.

8. McNeil Technologies (June 2003). "Feasibility Study of a Biomass Energy System for Boulder County Parks Department" p. 20. http://www.colorado.gov/energy/images/uploads/pdfs/ BCPOS_Final_Biomas_Report_web.pdf. Accessed June 23, 2009.

9. CTA Architects and Engineers et al. 2006. "Biomass Boiler Market Assessment." http://www.fuelsforschools.info/pdf/Final_Report_Biomass_Boiler_Market_Assessment.pdf. Accessed June 23, 2009.

10. United States Department of Agriculture, Forest Service, Timber Product Output Database (2002).

11. United States Census Bureau (January 2004). "2000 Population Data.” BioCycle Journal, State of Garbage in America.

12. http://www.nrbp.org/publications/biomass-chp/appendixa.pdf. Accessed June 26, 2009. 


\section{Appendix A. Biomass Resource Assessment [2]}

\section{Crop Residues}

The following crops were included in this analysis: Corn, wheat, soybeans, cotton, sorghum, barley, oats, rice, rye, canola, dry edible beans, dry edible peas, peanuts, potatoes, safflower, sunflower, sugarcane, and flaxseed. The quantities of crop residues that can be available in each county are estimated using total grain production, crop-to-residue ratio, moisture content, and consideration of the amount of residue left on the field for soil protection, grazing, and other agricultural activities [10].

\section{Forest Residues}

Forest residues are logging residues and other removable material left after carrying out silviculture operations and site conversions. Logging residue comprises unused portions of trees - cut or killed by logging and left in the woods. Other removable materials are the unused volume of trees that are cut or killed during logging operations [10].

\section{Primary Mill Residues}

Primary mill residues include wood materials (coarse and fine) and bark generated at manufacturing plants (primary wood-using mills) when round wood products are processed into primary wood products, such as slabs, edgings, trimmings, sawdust, veneer clippings and cores, and pulp screenings [10].

\section{Secondary Mill Residues}

Secondary mill residues include wood scraps and sawdust from woodworking shops-furniture factories, wood container and pallet mills, and wholesale lumberyards. Data on the number of businesses by county was gathered from the U.S. Census Bureau [11].

\section{Urban Wood Waste}

This analysis includes wood residues from municipal solid waste (MSW) (wood chips and pallets), utility tree trimming and private tree companies, and construction and demolition sites [11].

\section{Methane Emissions from Landfills}

The methane generation depends on three key factors: Total waste in place, landfill size, and location (arid or non-arid climate). Data is from EPA's Landfill Methane Outreach Program, 2003.

\section{Methane Emissions from Manure Management}

The following animal types were included in this analysis: Dairy cows, beef cows, hogs and pigs, sheep, chickens and egg layers, broilers, and turkey. The methane emissions were calculated by animal type and manure management system. Data is from USDA's National Agricultural Statistics Service, 2002.

\section{Methane Emissions from Wastewater Treatment Plants}

The methane generation of wastewater treatment plants (WWTP) is estimated using the methodology from the EPA "Inventory of U.S. Greenhouse Gas Emissions and Sinks: 19902003" [11]. 


\section{Appendix B. Direct Combustion System Manufacturers}

\begin{tabular}{|c|c|c|c|c|}
\hline $\begin{array}{c}\text { Company } \\
\text { Headquarters }\end{array}$ & $\begin{array}{l}\text { Biomass } \\
\text { Fuels }\end{array}$ & System Size & Comments & Contact Info \\
\hline $\begin{array}{l}\text { A3 Energy Partners } \\
\text { Portland, OR }\end{array}$ & $\begin{array}{l}\text { Wide range } \\
\text { of biomass }\end{array}$ & $\begin{array}{c}0.25 \text { to } \\
8.5 \mathrm{Mbtu} / \mathrm{hr}\end{array}$ & $\begin{array}{l}\text { Distributor of KÖB } \\
\text { Systems (Weissmann } \\
\text { Systems) }\end{array}$ & $\begin{array}{l}\text { Andrew Haden } \\
\text { 503-706-6187 } \\
\text { andrew@a3energypartners.com } \\
\text { www.a3energypartners.com/ }\end{array}$ \\
\hline $\begin{array}{l}\text { Advanced Recycling } \\
\text { Equipment } \\
\text { St. Marys, PA }\end{array}$ & $\begin{array}{l}\text { Wide range } \\
\text { of biomass }\end{array}$ & $\begin{array}{c}0.75 \text { to } \\
60 \mathrm{Mbtu} / \mathrm{hr}\end{array}$ & $\begin{array}{l}\text { Fixed-bed boiler } \\
\text { systems for heat }\end{array}$ & $\begin{array}{l}\text { 814-834-4470 } \\
\text { areinc@alltel.net } \\
\text { www.advancedrecyclingequip.com }\end{array}$ \\
\hline $\begin{array}{l}\text { AFS Energy } \\
\text { Systems } \\
\text { Lemoyne, PA }\end{array}$ & Wood & 3 to $27 \mathrm{Mbtu} / \mathrm{hr}$ & $\begin{array}{l}\text { Fixed-bed boiler } \\
\text { systems for heat }\end{array}$ & $\begin{array}{l}\text { 717-763-0286 } \\
\text { info@afsenergy.com } \\
\text { www.afsenergy.com }\end{array}$ \\
\hline $\begin{array}{l}\text { Bioheat USA } \\
\text { (Fröling) } \\
\text { Lyme, NH }\end{array}$ & $\begin{array}{l}\text { Pellets, } \\
\text { wood chips }\end{array}$ & $\begin{array}{c}0.07 \text { to } \\
0.2+\mathrm{Mbtu} / \mathrm{hr}\end{array}$ & $\begin{array}{l}\text { Fixed-bed boiler } \\
\text { systems for heat }\end{array}$ & $\begin{array}{l}\text { 800-782-9927 } \\
\text { info@bioheatusa.com } \\
\text { www.bioheatusa.com }\end{array}$ \\
\hline $\begin{array}{l}\text { Biomass Combus- } \\
\text { tion Systems } \\
\text { Worcester, MA }\end{array}$ & Wood & 3 to $40 \mathrm{Mbtu} / \mathrm{hr}$ & $\begin{array}{l}\text { Fixed-bed boiler } \\
\text { systems for heat }\end{array}$ & $\begin{array}{l}508-798-5970 \\
\text { info@biomasscombustion.com } \\
\text { www.biomasscombustion.com }\end{array}$ \\
\hline $\begin{array}{l}\text { Central Boiler } \\
\text { Greenbush, MN }\end{array}$ & $\begin{array}{l}\text { Wood } \\
\text { (e.g., pallets, } \\
\text { crates) }\end{array}$ & $\begin{array}{c}0.25 \text { to } \\
2 \mathrm{Mbtu} / \mathrm{hr}\end{array}$ & $\begin{array}{l}\text { Small-scale furnace } \\
\text { for forced air, boiler, } \\
\text { or radiant floor } \\
\text { heating system }\end{array}$ & $\begin{array}{l}\text { 218-782-2575 } \\
\text { infor@centralfireplace.com } \\
\text { www.centralboiler.com }\end{array}$ \\
\hline $\begin{array}{l}\text { Energy Products of } \\
\text { Idaho } \\
\text { Coeur d'Alene, ID }\end{array}$ & $\begin{array}{l}\text { Wide range } \\
\text { of biomass }\end{array}$ & $\begin{array}{c}15 \text { to } \\
160 \mathrm{Mbtu} / \mathrm{hr}\end{array}$ & $\begin{array}{l}\text { Fluidized-bed boiler } \\
\text { systems for heat, } \\
\text { power, or CHP }\end{array}$ & $\begin{array}{l}\text { 208-765-1611 } \\
\text { epi2@energyproducts.com } \\
\text { www.energyproducts.com }\end{array}$ \\
\hline $\begin{array}{l}\text { Fink Machine (KÖB) } \\
\text { Enderby, British } \\
\text { Columbia, Canada }\end{array}$ & Wood & $\begin{array}{c}0.27 \text { to } \\
8.5 \mathrm{Mbtu} / \mathrm{hr}\end{array}$ & $\begin{array}{l}\text { Fixed-bed boiler } \\
\text { systems for heat Fink } \\
\text { Machine is the } \\
\text { Canadian vendor for } \\
\text { KÖB (Austria) }\end{array}$ & $\begin{array}{l}\text { 250-838-0077 } \\
\text { info@finkmachine.com } \\
\text { www.finkmachine.com }\end{array}$ \\
\hline $\begin{array}{l}\text { Heatmor } \\
\text { Warroad, MN }\end{array}$ & Wood & $\begin{array}{c}0.45 \text { to } \\
0.8 \mathrm{Mbtu} / \mathrm{hr}\end{array}$ & Small-scale furnace & $\begin{array}{l}\text { 218-386-2769 } \\
\text { woodheat@heatmor.com } \\
\text { www.heatmor.com }\end{array}$ \\
\hline $\begin{array}{l}\text { Hurst Boilers } \\
\text { South Coolidge, GA }\end{array}$ & $\begin{array}{l}\text { Wide range } \\
\text { of biomass }\end{array}$ & $\begin{array}{c}0.4 \text { to } \\
56 \mathrm{Mbtu} / \mathrm{hr}\end{array}$ & $\begin{array}{l}\text { Fixed-bed boilers for } \\
\text { heat; can be used for } \\
\text { power production via } \\
\text { a steam turbine }\end{array}$ & $\begin{array}{l}\text { 877-994-8778 } \\
\text { info@hurstboiler.com } \\
\text { www.hurstboiler.com }\end{array}$ \\
\hline $\begin{array}{l}\text { King Coal Furnace } \\
\text { Corp Bismark, ND }\end{array}$ & Wood & $\begin{array}{c}3.4 \text { to } \\
34 \mathrm{Mbtu} / \mathrm{hr}\end{array}$ & $\begin{array}{l}\text { Fixed-bed, staged } \\
\text { combustion system }\end{array}$ & $\begin{array}{l}\text { 701-255-6406 } \\
\text { kingcoal@btinet.com } \\
\text { www.kingcoal.com }\end{array}$ \\
\hline $\begin{array}{l}\text { McBurney } \\
\text { Norcross, GA }\end{array}$ & Wood & $\begin{array}{c}20 \text { to } \\
80 \mathrm{Mbtu} / \mathrm{hr}\end{array}$ & $\begin{array}{l}\text { Medium- to large- } \\
\text { scale boiler systems } \\
\text { for industry }\end{array}$ & $\begin{array}{l}\text { 770-925-7100 } \\
\text { info@mcburney.com } \\
\text { www.mcburney.com }\end{array}$ \\
\hline $\begin{array}{l}\text { Messersmith } \\
\text { Bark River, MI }\end{array}$ & Wood & $\begin{array}{c}0.5 \\
\text { to10 } \mathrm{Mbtu} / \mathrm{hr}\end{array}$ & $\begin{array}{l}\text { Fixed-bed boiler } \\
\text { systems for heat }\end{array}$ & $\begin{array}{l}\text { 906-466-9010 } \\
\text { sales@burnchips.com } \\
\text { www.burnchips.com }\end{array}$ \\
\hline
\end{tabular}




\begin{tabular}{|c|c|c|c|c|}
\hline $\begin{array}{c}\text { Company } \\
\text { Headquarters }\end{array}$ & $\begin{array}{l}\text { Biomass } \\
\text { Fuels }\end{array}$ & System Size & Comments & Contact Info \\
\hline $\begin{array}{l}\text { Pro-Fab Industries } \\
\text { Arborg, Manitoba, } \\
\text { Canada }\end{array}$ & Wood, corn & $\begin{array}{c}0.75 \text { to } \\
2.5 \mathrm{Mbtu} / \mathrm{hr}\end{array}$ & $\begin{array}{l}\text { Pre-Fab makes the } \\
\text { Pelco, a light } \\
\text { industrial, hot-water } \\
\text { boiler }\end{array}$ & $\begin{array}{l}204-364-2211 \\
\text { info@profab.com } \\
\text { www.profab.com }\end{array}$ \\
\hline $\begin{array}{l}\text { Propell Energy } \\
\text { Jaffrey, } \mathrm{NH}\end{array}$ & Pellets & $\begin{array}{c}0.5 \text { to } \\
10 \mathrm{Mbtu} / \mathrm{hr}\end{array}$ & $\begin{array}{l}\text { Automatic pellet } \\
\text { systems for } \\
\text { commercial and } \\
\text { industrial systems } \\
\end{array}$ & $\begin{array}{l}603.532 .4668 \text {, ext. } 214 \\
\text { jgoodyear@propellenergy.com } \\
\text { www.propellenergy.com }\end{array}$ \\
\hline $\begin{array}{l}\text { SolaGen } \\
\text { St. Helens, OR }\end{array}$ & $\begin{array}{l}\text { Chips, } \\
\text { pellets }\end{array}$ & $\begin{array}{c}0.5 \text { to } \\
50 \mathrm{Mbtu} / \mathrm{hr}\end{array}$ & $\begin{array}{l}\text { Chip or pellet systems } \\
\text { for commercial and } \\
\text { industrial applications }\end{array}$ & $\begin{array}{l}\text { 503-366-4210 } \\
\text { solagen@solagenic.com } \\
\text { http://www.solageninc.com/ }\end{array}$ \\
\hline $\begin{array}{l}\text { Wellons, Inc. } \\
\text { Vancouver, WA }\end{array}$ & Wood & 5 to $10 \mathrm{Mbtu} / \mathrm{hr}$ & $\begin{array}{l}\text { Boiler systems } \\
\text { designed for the } \\
\text { forest products } \\
\text { industry }\end{array}$ & $\begin{array}{l}\text { 360-750-3500 } \\
\text { sales@wellons.com } \\
\text { www.wellonwusa.com }\end{array}$ \\
\hline
\end{tabular}




\section{Appendix C. Direct Combustion, Direct-Fired, and Indirect-Fired Technology Companies}

\begin{tabular}{|c|c|c|c|c|c|}
\hline $\begin{array}{c}\text { Company } \\
\text { Headquarters }\end{array}$ & Fuels & $\begin{array}{l}\text { System } \\
\text { Size }\end{array}$ & $\begin{array}{l}\text { Approximate } \\
\text { Number of } \\
\text { Units } \\
\text { Operating in } \\
\text { the United } \\
\text { States } \\
\end{array}$ & Comments & Contact Info \\
\hline $\begin{array}{l}\text { AgriPower, Inc., } \\
\text { New York, NY }\end{array}$ & Variety & $300 \mathrm{~kW}$ & 1 & $\begin{array}{l}\text { Utilizes an "open" } \\
\text { Brayton Cycle process } \\
\text { in CHP unit, using hot } \\
\text { air (the working fluid) to } \\
\text { drive the turbine }\end{array}$ & $\begin{array}{l}\text { 516-829-2000 } \\
\text { www.agripower.com }\end{array}$ \\
\hline $\begin{array}{l}\text { Zilkha Biomass } \\
\text { Energy, } \\
\text { Houston, TX }\end{array}$ & Wood & $\begin{array}{c}1.5 \mathrm{MW} \\
\text { to } \\
4.5 \mathrm{MW}\end{array}$ & 1 & $\begin{array}{l}\text { CHP pressurized direct } \\
\text { combustion system; } \\
\text { only operating unit is } \\
\text { colocated with a New } \\
\text { England wood pellet } \\
\text { production facility }\end{array}$ & $\begin{array}{l}\text { 713-979-9962 } \\
\text { Iweick@zilkhabiomass.com } \\
\text { www.zilkha.com }\end{array}$ \\
\hline
\end{tabular}




\section{Appendix D. Gasification Technology Companies}

\begin{tabular}{|c|c|c|c|c|c|c|}
\hline $\begin{array}{c}\text { Company } \\
\text { Headquarters }\end{array}$ & $\begin{array}{c}\text { Use of } \\
\text { Gas }\end{array}$ & Fuels & $\begin{array}{l}\text { System } \\
\text { Size }\end{array}$ & $\begin{array}{l}\text { Approximate } \\
\text { Number of } \\
\text { Units Operat- } \\
\text { ing in the } \\
\text { United States }\end{array}$ & Comments & Contact Info \\
\hline $\begin{array}{l}\text { AdaptiveARC } \\
\text { San Diego, CA }\end{array}$ & Diverse & $\begin{array}{l}\text { Wood, } \\
\text { ag, MSW }\end{array}$ & $\begin{array}{l}100+\text { tons } \\
\text { biomass } \\
\text { per day }\end{array}$ & $\begin{array}{c}0 \\
\text { (prototype } \\
\text { phase) }\end{array}$ & $\begin{array}{l}\text { Cool plasma arc } \\
\text { gasification }\end{array}$ & $\begin{array}{l}\text { 858-525-1133 } \\
\text { info@adaptiveARC.com } \\
\text { www.adaptiveARC.com }\end{array}$ \\
\hline $\begin{array}{l}\text { Alternative Energy } \\
\text { Solutions } \\
\text { (Uniconfort) } \\
\text { Wichita, KS }\end{array}$ & $\begin{array}{l}\text { Close } \\
\text { coupled }\end{array}$ & $\begin{array}{l}\text { Wood, } \\
\text { ag. } \\
\text { residues }\end{array}$ & $\begin{array}{l}1 \text { to } 20 \\
\text { Mbtu/hr }\end{array}$ & $\begin{array}{c}1(25 \text { in } \\
\text { development for } \\
2009-2010 \text { in } \\
\text { the United } \\
\text { States); } 3,500 \\
\text { installed } \\
\text { worldwide }\end{array}$ & $\begin{array}{l}\text { Alternative Energy } \\
\text { Solutions, a subsidi- } \\
\text { ary of Wichita Boiler, } \\
\text { is the exclusive } \\
\text { North American } \\
\text { licensee for } \\
\text { Uniconfort (Italy); } \\
\text { close-coupled gasifi- } \\
\text { cation systems that } \\
\text { produce heat, power, } \\
\text { and CHP }\end{array}$ & $\begin{array}{l}\text { 316-201-4143 } \\
\text { info@aesenergy.net } \\
\text { www.aesenergy.net }\end{array}$ \\
\hline $\begin{array}{l}\text { ChipTec Wood } \\
\text { Energy } \\
\text { South Burlington, VT }\end{array}$ & $\begin{array}{l}\text { Close } \\
\text { coupled }\end{array}$ & Wood & $\begin{array}{l}1.5 \text { to } 125 \\
\text { Mbtu/hr }\end{array}$ & $175+$ & $\begin{array}{l}\text { Crossdraft boiler } \\
\text { systems; large scale } \\
\text { close-coupled } \\
\text { gasifiers }\end{array}$ & $\begin{array}{l}\text { 800-244-4146 } \\
\text { chiptec@ together.net } \\
\text { www.chiptec.com }\end{array}$ \\
\hline $\begin{array}{l}\text { Nexterra Energy } \\
\text { Vancouver, British } \\
\text { Columbia, Canada }\end{array}$ & $\begin{array}{l}\text { Close } \\
\text { coupled }\end{array}$ & $\begin{array}{l}\text { Wood, } \\
\text { switch- } \\
\text { grass, } \\
\text { e-grass, } \\
\text { misc. } \\
\text { paper }\end{array}$ & $\begin{array}{l}7 \text { to } 144 \\
\text { Mbtu/hr }\end{array}$ & \begin{tabular}{|c|}
1 ( 4 in \\
development, \\
including at Oak \\
Ridge National \\
Lab); 3 in \\
operation in \\
Canada
\end{tabular} & $\begin{array}{l}\text { Systems are } \\
\text { operating at pulp- } \\
\text { paper mills; system } \\
\text { to be built at Oak } \\
\text { Ridge National Lab } \\
\text { to displace existing } \\
\text { natural-gas steam } \\
\text { plant utilizing locally } \\
\text { sourced woody } \\
\text { biomass }\end{array}$ & $\begin{array}{l}\text { 604-637-2502 } \\
\text { cdunaway@nexterra.ca } \\
\text { www.nexterra.ca }\end{array}$ \\
\hline $\begin{array}{l}\text { Primenergy } \\
\text { Tulsa, OK }\end{array}$ & $\begin{array}{l}\text { Close } \\
\text { coupled }\end{array}$ & $\begin{array}{l}\text { Wood, } \\
\text { corn fiber, } \\
\text { carpet } \\
\text { scraps }\end{array}$ & $\begin{array}{l}18 \mathrm{Mbtu} / \mathrm{hr} \\
\text { (or more) }\end{array}$ & $6 ; 1$ in Italy & $\begin{array}{l}\text { Updraft, fixed-bed } \\
\text { gasification systems; } \\
\text { most systems have } \\
\text { onsite feedstocks }\end{array}$ & $\begin{array}{l}918-835-1011 \\
\text { bteitze@ primenergy.com } \\
\text { www.primenergy.com }\end{array}$ \\
\hline $\begin{array}{l}\text { PRM Energy } \\
\text { Systems } \\
\text { Hot Springs, AR }\end{array}$ & $\begin{array}{l}\text { Close } \\
\text { coupled }\end{array}$ & $\begin{array}{l}\text { Variety of } \\
\text { biomass; } \\
\text { rice husk/ } \\
\text { straw }\end{array}$ & $\begin{array}{l}13 \text { to } 118 \\
\text { Mbtu/hr; } \\
1-15 \mathrm{MW}\end{array}$ & $\begin{array}{l}5 \text { to } 6 \text { in the } \\
\text { United States; } \\
25 \text { worldwide }\end{array}$ & $\begin{array}{l}\text { Close-coupled } \\
\text { gasification systems } \\
\text { that produce heat, } \\
\text { power, and CHP; } \\
\text { most systems have } \\
\text { onsite feedstock; } 1 \\
\text { project has wood } \\
\text { waste brought to an } \\
\text { ethanol plant to } \\
\text { provide heat }\end{array}$ & $\begin{array}{l}\text { 501-767-2100 } \\
\text { info@prmenergy.com } \\
\text { www.prmenergy.com }\end{array}$ \\
\hline $\begin{array}{l}\text { Frontline Bioenergy } \\
\text { Ames, IA }\end{array}$ & $\begin{array}{l}\text { Two } \\
\text { staged }\end{array}$ & $\begin{array}{l}\text { Wood } \\
\text { residues, } \\
\text { corn } \\
\text { stover, } \\
\text { switch- } \\
\text { grass }\end{array}$ & $\begin{array}{c}100 \\
\mathrm{Mbtu} / \mathrm{hr}\end{array}$ & 1 & $\begin{array}{l}\text { The integrated } \\
\text { biomass gasification } \\
\text { system currently in } \\
\text { operation utilizes } \\
\text { wood and ag wastes } \\
\text { to offset natural gas } \\
\text { use at an ethanol } \\
\text { plant in Minnesota }\end{array}$ & $\begin{array}{l}\text { 515-292-1200 } \\
\text { www.energyproducts.com }\end{array}$ \\
\hline
\end{tabular}




\begin{tabular}{|c|c|c|c|c|c|c|}
\hline $\begin{array}{c}\text { Company } \\
\text { Headquarters }\end{array}$ & $\begin{array}{c}\text { Use of } \\
\text { Gas }\end{array}$ & Fuels & $\begin{array}{l}\text { System } \\
\text { Size }\end{array}$ & $\begin{array}{l}\text { Approximate } \\
\text { Number of } \\
\text { Units Operat- } \\
\text { ing in the } \\
\text { United States } \\
\end{array}$ & Comments & Contact Info \\
\hline $\begin{array}{l}\text { Community Power } \\
\text { Corp. } \\
\text { Littleton, CO }\end{array}$ & $\begin{array}{l}\text { Two } \\
\text { staged }\end{array}$ & $\begin{array}{l}\text { Variety of } \\
\text { biomass }\end{array}$ & 5 to $100 \mathrm{~kW}$ & $\begin{array}{c}1 \text { operating } 24 \\
\text { hrs/day } 7 \text { days } \\
\text { per week; } 6 \\
\text { demonstration } \\
\text { units } \\
\end{array}$ & $\begin{array}{l}\text { Small-scale, modular } \\
\text { gasifier-genset unit } \\
\text { designed to provide } \\
\text { distributed CHP }\end{array}$ & $\begin{array}{l}303 \text { 933-3135 } \\
\text { rwalt@gocpc.com } \\
\text { www.gocpc.com }\end{array}$ \\
\hline $\begin{array}{l}\text { Energy \& Environ- } \\
\text { mental Research } \\
\text { Center (EERC) } \\
\text { Grand Forks, ND }\end{array}$ & $\begin{array}{l}\text { Two } \\
\text { staged }\end{array}$ & $\begin{array}{l}\text { Variety of } \\
\text { biomass }\end{array}$ & $\begin{array}{l}100 \mathrm{~kW} \text { to } \\
1 \mathrm{MW}\end{array}$ & $\begin{array}{c}2 \text { (both } \\
\text { demonstration } \\
\text { units) }\end{array}$ & $\begin{array}{l}\text { Developing a } \\
\text { microgasification } \\
\text { technology that } \\
\text { utilizes the com- } \\
\text { bustible gas in a } \\
\text { piston engine } \\
\text { generator for power } \\
\text { production }\end{array}$ & $\begin{array}{l}\text { 701-777-5120 } \\
\text { dschmidt@undeerc.org } \\
\text { www.undeerc.org }\end{array}$ \\
\hline $\begin{array}{l}\text { Cratech } \\
\text { Tahoka, TX }\end{array}$ & $\begin{array}{l}\text { Diverse } \\
\text { use }\end{array}$ & $\begin{array}{l}\text { Variety of } \\
\text { biomass }\end{array}$ & $\begin{array}{l}5,10, \text { and } \\
20 \mathrm{MW}\end{array}$ & $\begin{array}{c}0 \\
(2 \text { in } \\
\text { development })\end{array}$ & $\begin{array}{l}\text { Developing a } \\
\text { pressurized fluidized- } \\
\text { bed gas turbine } \\
\text { system }\end{array}$ & $\begin{array}{l}8063275220 \\
\text { info@cratech.com } \\
\text { http://cratech.com }\end{array}$ \\
\hline $\begin{array}{l}\text { Diversified Energy } \\
\text { Gilbert, AZ }\end{array}$ & $\begin{array}{l}\text { Diverse } \\
\text { use }\end{array}$ & $\begin{array}{l}\text { Variety of } \\
\text { biomass }\end{array}$ & $\begin{array}{c}50 \text { to } 300 \\
\mathrm{Mbtu} / \mathrm{hr}\end{array}$ & 1 (pilot plant) & $\begin{array}{l}\text { Developing a molten } \\
\text { metals-based } \\
\text { gasification } \\
\text { technology }\end{array}$ & $\begin{array}{l}\text { 480-507-0297 } \\
\text { business@ } \\
\text { diversified-energy.com } \\
\text { www.diversified- } \\
\text { energy.com }\end{array}$ \\
\hline $\begin{array}{l}\text { Thermogenics } \\
\text { Albuquerque, NM }\end{array}$ & $\begin{array}{l}\text { Diverse } \\
\text { use }\end{array}$ & $\begin{array}{l}\text { Variety of } \\
\text { biomass }\end{array}$ & $\begin{array}{l}2 \text { to } 200 \\
\text { Mbtu/hr }\end{array}$ & 1 & $\begin{array}{l}\text { Bottom-fed inverted } \\
\text { downdraft gasifier }\end{array}$ & $\begin{array}{l}505-463-8422 \\
\text { thermogenics@ } \\
\text { thermogenics.com } \\
\text { www.thermogenics.com }\end{array}$ \\
\hline
\end{tabular}




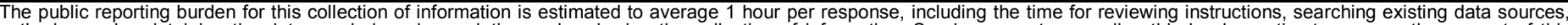

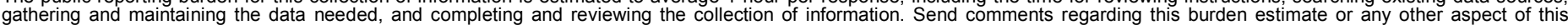

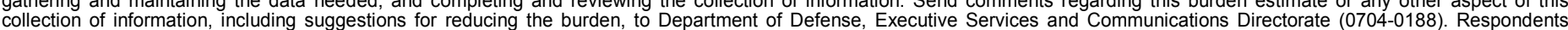

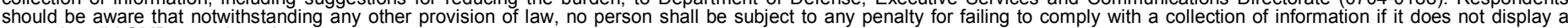

chould be aware that notwilhstandin

PLEASE DO NOT RETURN YOUR FORM TO THE ABOVE ORGANIZATION.

\begin{tabular}{|l|l|l|l} 
1. REPORT DATE (DD-MM-YYYY) & 2. REPORT TYPE & 3. DATES COVERED (FrOm - TO)
\end{tabular} July 2009

Technical report

4. TITLE AND SUBTITLE

Market Assessment of Biomass Gasification and Combustion

Technology for Small- and Medium-Scale Applications

5a. CONTRACT NUMBER

DE-AC36-08-GO28308

5b. GRANT NUMBER

5c. PROGRAM ELEMENT NUMBER

5d. PROJECT NUMBER

NREL/TP-7A2-46190

5e. TASK NUMBER

IGST.9034

5f. WORK UNIT NUMBER
7. PERFORMING ORGANIZATION NAME(S) AND ADDRESS(ES)

National Renewable Energy Laboratory

1617 Cole Blvd.

Golden, CO 80401-3393

9. SPONSORING/MONITORING AGENCY NAME(S) AND ADDRESS(ES)
8. PERFORMING ORGANIZATION REPORT NUMBER

NREL/TP-7A2-46190

10. SPONSOR/MONITOR'S ACRONYM(S) NREL

11. SPONSORING/MONITORING AGENCY REPORT NUMBER

\section{DISTRIBUTION AVAILABILITY STATEMENT}

National Technical Information Service

U.S. Department of Commerce

5285 Port Royal Road

Springfield, VA 22161

13. SUPPLEMENTARY NOTES

\section{ABSTRACT (Maximum 200 Words)}

This report provides a market assessment of gasification and direct combustion technologies that use wood and agricultural resources to generate heat, power, or combined heat and power (CHP) for small- to medium-scale applications. It contains a brief overview of wood and agricultural resources in the U.S.; a description and discussion of gasification and combustion conversion technologies that utilize solid biomass to generate heat, power, and $\mathrm{CHP}$; an assessment of the commercial status of gasification and combustion technologies; a summary of gasification and combustion system economics; a discussion of the market potential for small- to medium-scale gasification and combustion systems; and an inventory of direct combustion system suppliers and gasification technology companies. The report indicates that while direct combustion and close-coupled gasification boiler systems used to generate heat, power, or CHP are commercially available from a number of manufacturers, two-stage gasification systems are largely in development, with a number of technologies currently in demonstration. The report also cites the need for a searchable, comprehensive database of operating combustion and gasification systems that generate heat, power, or CHP built in the U.S., as well as a national assessment of the market potential for the systems.

\section{SUBJECT TERMS}

biomass; biopower; gasification; combined heat and power; CHP; wood heat; direct combustion

\begin{tabular}{|c|c|c|}
\hline . SECURIT & CLASSIFICATI & N OF: \\
\hline $\begin{array}{l}\text { a. REPORT } \\
\text { Unclassified }\end{array}$ & $\begin{array}{l}\text { b. ABSTRACT } \\
\text { Unclassified }\end{array}$ & $\begin{array}{l}\text { c. THIS PAGE } \\
\text { Unclassified }\end{array}$ \\
\hline
\end{tabular}

\begin{tabular}{|c|c|}
\hline $\begin{array}{l}\text { 17. LIMITATION } \\
\text { OF ABSTRACT }\end{array}$ & $\begin{array}{l}\text { 18. NUMBER } \\
\text { OF PAGES }\end{array}$ \\
\hline UL & \\
\hline
\end{tabular}

19a. NAME OF RESPONSIBLE PERSON

19b. TELEPHONE NUMBER (Include area code) 